M.A. Lekas

J.M. Lekas

F.G. Strickland

May 1991

Work Performed Under Cooperative Agreemeni No.: DE-FC21-86MC11076

For

U.S. Department of Energy

Office of Fossil Energy

Morgantown Energy Technology Center

Morgantown, West Virginia

By

Western Research Institute

Laramie, Wyoming 


\section{DISCLAIMER}

This report was prepared as an account of work sponsored by an agency of the United States Government. Neither the United States Government nor any agency thereof, nor any of their employees makes any warranty, express or implied, or assumes any legal liability or responsibility for the accuracy, completeness or usefulness of any information, apparatus, product, or process disclosed, or represents that its use would not infringe privately owned rights. R.eference herein to any specific commercial product, process, or service by trade name, trademark, manufacturer, or otherwise, does not necessarily constitute or imply its endorsement, recommendation, or favoring by the United States Government or any agency thereof. The views and opinions of authors expressed herein do not necessarily state or reflect those of the United States Government or any agency thereof.

This report has been reproduced directly from the best available copy.

Available to DOE and DOE contractors from the Office of Scientific and Technical Information, P.O. Box 62, Oak Ridge, TN 37831; prices available from (615)576-8401, FTS 626-8401.

Available to the public from the National Technical Information Service, U.S. Department of Commerce, 5285 Port Royal Rd., Springfield, VA 22161. 


\title{
Initial Evaluation of Fracturing Oil Shale With \\ Propellants for In Situ Retorting - Phase 2
}

\author{
Topical Report
}

M.A. Lekas

J.M. Lekas

F.G. Strickland

Work Performed Under Cooperative Agreement No.: DE-FC21-86MC11076

For

U.S. Department of Energy

Office of Fossil Energy

Morgantown Energy Technology Center

P.O. Box 880

Morgantown, West Virginia 26507-0880

By

Western Research Institute

P.O. Box 3395

University Station

Laramie, Wyoming 82071

May 1991 
TABLE OF CONTENTS

Page

LIST OF TABLES........................... iv

LIST OF FIGURES $\ldots \ldots \ldots \ldots \ldots \ldots \ldots \ldots \ldots \ldots \ldots \ldots \ldots \ldots \ldots$

SUMMARY $\ldots \ldots \ldots \ldots \ldots \ldots \ldots \ldots \ldots \ldots \ldots \ldots \ldots \ldots \ldots \ldots \ldots \ldots \ldots$

INTRODUCTION .............................. 1

DESIGN OF FIRING SYSTEM AND PROPELLANT TOOLS............ 3

EXPERIMENTAL PLAN............................. 5

EXPERIMENTAL OPERATIONS......................... 6

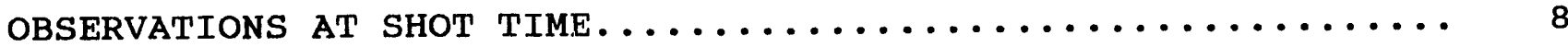

OBSERVATIONS IN CORES........................... 11

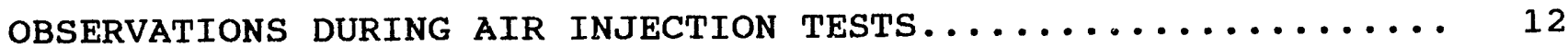

CONCLUSIONS................................ 15

DISCLATMER .............................. 16

ACKNOWLEDGEMENTS. ............................. 16 


\section{LIST OF TABLES}

\section{Page}

Table 1. Summary of propellant tool parameters........... 19

Table 2. Summary of air injection data.............. 20

Table 3. Air injection at holes adjacent to 25-pound shot.... 15 
LIST OF FIGURES

Figure

Page

1. 60 -pound propellant tool................... 17

2. Shot induced horizontal fracture in postshot core.... 17

3. Water being ejected from observation hole at shot time 18

4. Test \#3. Layout of drill holes................ 21

5. Test \#3. Surface fractures created by shots........ 22

6. Test \#4. Layout of drill holes................ 23

7. Test \#5. Layout of drill holes................ 24

8. Test \#6. Layout of drill holes............... 25

9. Test \#3. Flow rates, hole $30 B 1 \ldots \ldots \ldots \ldots \ldots \ldots \ldots \ldots . . . . .26$

10. Test \#3. Flow rates, hole $3 c 2 \ldots \ldots \ldots \ldots \ldots \ldots \ldots \ldots \ldots$

11. Test \#4. Flow rates, hole $40 B 1 \ldots \ldots \ldots \ldots \ldots \ldots \ldots \ldots \ldots . . \ldots$

12. Test \#4. Flow rates, hole $40 B 3 \ldots \ldots \ldots \ldots \ldots \ldots \ldots \ldots . . . . .29$

13. Test \#4. Flow rates, hole $4 \mathrm{C} 3 \ldots \ldots \ldots \ldots \ldots \ldots \ldots \ldots \ldots$

14. Test \#4. Flow rates, hole 4 C4................ 31

15. Test \#4. Flow rates, hole 4 C5................ 32

16. Test \#4. Flow rates, hole 4 c6............... 33

17. Test \#4. Flow rates, hole 4 C7................ 34

18. Test \#5. Flow rates, hole 50B1............... 35

19. Test \#5. Flow rates, hole 50B2.............. 36

20. Test \#5. Flow rates, hole 5 c1................ 37

21. Test \#5. Flow rates, hole $5 \mathrm{C} 4 \ldots \ldots \ldots \ldots \ldots \ldots \ldots \ldots . \ldots 38$

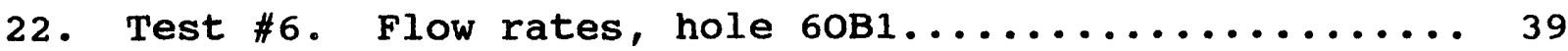


A series of field experiments was carried out to gather preliminary information on the use of propellant charges to create horizontal fractures in oil shale beds for in situ retorting. Development of a propellant tool specifically designed to create horizontal fractures, and testing of various sizes and designs of the tool to create fractures in oil shale beds were carried out simultaneously. Ten prototype tools with energy yields from 2 pounds to 60 pounds were fired at depths ranging from 10 feet to 60 feet. Ten preshot observation holes and 13 postshot core holes were used to gather information and to serve as injection wells to inject air into the formation for permeability tests. Most shots vented large volumes of gas or water from observation holes 13 to 20 feet distant, indicating that a horizontal fracture communicating from the shot point to the observation hole had been created. Shot-related horizontal fracturing was noted in most core holes at the same depth as the shot point. Air injection tests on all holes showed a significant increase in permeability after the shots. 
INTRODUCTION

\section{Purpose}

Propellant charges have been developed for fracturing oil and gas wells to increase formation permeability, and propellant fracturing services are available to the oil industry on a commercial basis. The purpose of this project was to carry out preliminary investigations on the use of similar propellant charges to create fractures in oil shale as a basis for an in situ extraction process.

Field tests on the use of explosives for fracturing oil shale in situ have been carried out by the U. S. Bureau of Mines, Sandia National Laboratory, and Talley Energy Systems Inc. in Wyoming; by the Dow Chemical Company in Michigan; and by Geokinetics Inc. in Utah. The Geokinetics tests were the most extensive, involving the fracturing of 883,000 tons of oil shale with 630 tons of explosive and recovering 136,000 barrels of shale oil.

In the Geokinetics process, a series of millisecond timedelayed charges emplaced in vertical drill holes in the oil shale are used to raise the overburden and fracture the oil shale bed. Most of the explosive energy is consumed to accelerate the mass of overburden upward to create expansion space for the fractured oil shale. If the overburden could be raised by gas pressure, rather than being accelerated upward by explosive energy, the process would be more efficient, and greater thicknesses of overburden could be lifted.

Propellants differ from explosives in that the energy is released more slowly, in the form of high pressure gas, rather than largely as a gas-generated shock wave. The high-pressure gas from the propellant can create fractures and raise overburden.

The testing was carried out for use in shale oil extraction. However, the technology being investigated is a generic method for creating controlled fractures that can be used for many other purposes.

Propellant charges and firing systems for the tests were provided by Hi Tech Natural Resources Inc. of Salt Lake City, Utah. Hi Tech Natural Resources develops and markets propeliant tools for oil and gas well stimulation under the trade name Radialfrac. In Phase 1 of the program, the charges utilized in the tests were a standard oil field type Radialfrac tool, 11 feet long, 3 inches in diameter, and containing 40 pounds of propellant. These tools created a combination of horizontal and vertical fractures with vertical fractures predominating. 
The primary purpose of the Phase 2 program was to develop a propellant tool and firing system specifically intended for creating horizontal fractures at shallow depth, and to test the design in bore holes in an oil shale bed to determine if horizontal fractures were created. Secondary objectives were to conduct tests to determine permeability changes in the formation induced by the charges and take core drill samples through the fractured section to observe the nature of the fracturing.

\section{Scope}

The scope of Phase 2 of the program was determined by the availability of funds $(\$ 73,500)$. For this reason, no instrumentation was used to record gas pressure buildup and decline history during shot time or to observe the dynamic behavior of the fractures. By firing small charges at shallow depth in oil shale beds, investigating the fracture effects by drilling postblast core holes, and conducting air injection tests, we sought to establish qualitatively, and a minimum cost, the following:

1. Will the tool design ignite and deflagrate?

2. Are horizontal fractures created?

3. What is the appearance of the fractures as observed in core holes?

4. What changes in formation permeability are created by the fractures?

5. Observe variations in effects as the energy yield, tool design, and depth of burial are changed.

Later programs will involve instrumented tests. These will investigate the effects of interacting charges fired simultaneously or with millisecond delays and the effects of firing propellant charges and explosives either simultaneously or with millisecond delays.

\section{Summary of Prior Work}

A series of field experiments were carried out from August 1988 to June 1989 to gather preliminary information on the use of propellant charges to fracture oil shale for in situ retorting (Lekas et al, 1989).

Three propellant charges were fired at a depth of 60 feet, two in one hole, and the third in a second hole. The charges were commercialiy available tools provided by Hi Tech Natural Resources Inc. of Salt Lake City, Utah. The tools were designed 
for fracturing oil wells to improve the fluid flow characteristics of the well.

The tools were 11 feet long, 3 inches in diameter, and contained a 40-pound charge of propellant. The tools had a center line ignitor and were intended to create vertical fractures.

Six angle holes were drilled ( 3 at each shot site) to observe the fractures in the cores and to provide access to the fracture zone for air injection tests. Thirteen air injection tests were carried out. Horizontal and vertical fractures were observed in the core, and substantial increases over natural permeability were observed in the air injection tests.

Designation of Test Holes

In this report, all holes are identified by a code that gives the test number, the type of hole, and the hole number. The first number in the code is the number of the test, the letters indicate the type of hole (OB = observation hole, $\mathrm{SH}=$ shot hole, $C=$ core hole), and the last number is the hole number. All holes of a given type within a test are in consecutive order. For example, $4 \mathrm{SH} 2$ is part of test \#4, is a shot hole, and its number designation is 2 .

\section{DESIGN OF PROPELLANT TOOLS AND FIRING SYSTEM}

In addition to the field tests to observe effects, steps were taken to design a propellant tool specifically intended to create horizontal fractures at shallow depths (up to 500 feet in depth) and to develop a safe and reliable firing system.

For tools used in oil field applications, an electric cap is used to ignite the propellant charge. To avoid the inherent dangers in use of blasting caps, an electric high-energy ignition system was developed by $\mathrm{Hi}$ Tech Natural Resources to ignite the charge. To improve the reliability of the ignition system, a backup system was incorporated in the tool, with two independent ignitors. It was necessary to exercise great care to seal the tool against moisture invasion, as the ignition system was sensitive to moisture.

Commercially available propellant tools are designed to generate vertical fractures in the formations adjacent to oil wells. They normally create 4 to 6 vertical fractures radiating from the well bore for a distance of 10 to 30 feet. Hi Tech Natural Resources of Salt Lake city provides such tools and firing services to the oil industry under the trade name Radialfrac. The tools are generally 10 to 12 feet long, 3 to 4 inches in diameter, and contain 40 to 60 pounds of propellant. 
Combinations of tools can be designed for fracturing thicker formations. Fracturing is performed in cased and perforated wells. The high-pressure gases exit the well through the perforations with no damage to the casing or casing cement. This type of tool is initiated by an ignitor rod running down the axis of the tool. Upon firing, the ignitor initiates deflagration of the propellant charge. The propellant burns from the axis of the tool to the periphery, and the gases generated bring pressure along the length of the tool. The gases pressure the formation with a force that tends to split the formation in a vertical plane, creating vertical fractures.

In the concept for a tool to create horizontal fractures, the charge is initiated at a point, usually at the bottom of the tool. The propellant will burn along the axis of the tool, away from the point of ignition, generating a continuing supply of gas. If the propellant is encased in a steel shell with a horizontal slot at the ignition point, the gases will pressure the formation in a horizontal plane, tending to create a single horizontal fracture. The gases will be fed through the slot to the fracture, extending and enlarging the fracture.

The extent of the fracture, its transient width, and the magnitude of transient surface uplift (bounce) will be affected by the amount of high-pressure gas generated by the tool and the rate at which the gas is fed to the fracture. The rate of gas generation can te controlled by changing the composition of the propellant and by changing the cross sectional area of the tool. In the 10 tools fired, the composition of the propellant was a constant. The cross-sectional areas ranged from 1.8 square inches to 28 square inches, and the total weight of propellant ranged from one pound to 60 pounds. See Table 1 for a summary of the tool dimensions. In all cases except one, the slot and ignitor were located at the bottom of the tool. In shot 4SH3, the ignitor and slot were at the center of the tool, allowing the propellant to burn in 2 directions, and doubling the rate of release of gas to the formation.

In test \#4, three charges of equal weight were fired at 30 feet. Two charges had a cross section of 10 square inches, and the other charge had an area of 5 square inches. Both shots with the larger area had an observable surface bounce, and the charge with the smaller area showed no bounce. The faster rate of gas release related to the larger area resulted in the visible transient surface uplift.

Figure 1 shows the 60-pound propellant tool fired in hole 6SH1. Figure 2 shows a section of core with a horizontal fracture created by a shot at a distance of 3 feet from the shot hole. Figure 3 shows a typical plume of water being ejected $f$ :om a water-filled observation hole at shot time. 


\section{EXPERIMENTAL PLAN}

The following experimental plan was established for the test program:

1. Design a propellant tool to create horizontal fractures.

2. Develop and test a safe and reliable firing system with backup capability. For safety purposes, the system will not use conventional blasting caps, either electric or nonelectric.

3. Develop and test a safe and reliable ignitor that will be located at the end of the tool, will be initiated by the firing system, and will effectively ignite the propellant charge.

4. Emplace variations of the design in concrete blocks and fire. The purpose is to test the firing system, test the ignitor system, and observe the effects of the various designs in fracturing the blocks.

5. Select the most effective of the designs and emplace in an oil shale bed at shallow depth ( 10 feet) to observe effects in the ground.

6. At an intermediate depth (30 feet), test a number of variations of tool design and select the most effective design.

7. Test the most effective design at greater depth (60 feet). Compare the effects of variations in yield.

8. Fire a large charge at intermediate depth to determine the effect of a major increase in energy yield.

All shots in the ground will have one or more preshot observation holes located 13 to 20 feet from the shot hole drilled deeper than the bottom of the propellant tool. Venting of large volumes of gas or water from the observation hole will be considered as evidence of a horizontal, or near horizontal, fracture, as the probability of a steeply dipping fracture intersecting the open section of the observation hole is low.

All shots in the ground will reve adjacent postshot core holes drilled deeper than the propellant tool. Cores will be examined for evidence of shot-induced fractures.

Air injection tests will be run on all open holes, including observation holes and core holes. Each test site will have at 
least one preshot air injection test. Air tests will include hole-to-formation and hole-to-hole tests.

\section{EXPERIMENTAL OPERATIONS}

Field work began in August 1989 and was completed in February 1991. The initial step was to fabricate and fire four small test charges emplaced in propellant containers to create horizontal fractures. These charges were 2 inches in diameter and 6 inches long. The charges were emplaced in cement cylinders 2 feet in diameter and $2 \frac{1}{2}$ feet high.

In order to improve the safety characteristics of the propellant tools, it was decided to replace the electric cap initiator, normally used in commercial tools, with a high-energy initiator. This type of initiator was used in all the tests.

Test \#1 was carried out in August and September 1989. Of the four charges, two fired as planned, and two were misfires. It was concluded that the misfires were caused by the use of a long (400 foot) firing line that reduced the current delivered to the ignitor. Firing procedures were revised to use a system located close to the tool as an energy source. The cement cylinders in the two test blocks that fired shattered the blocks. Therefore, it was decided to reduce the size of the charges for Test \#2.

Test \#2 used three smaller test charges, 3 inches long, and $1 / 2$ to $3 / 4$ inches in diameter. These charges were emplaced in cement test blocks 2 feet in diameter and $2 \frac{1}{2}$ feet long. on November 18, 1989, the tests were fired using the high-energy ignitor. On all three charges, the ignitor fired but failed to ignite the main propellant charge. It was concluded that this failure was due to the small cross section of the charges and the ignitor not permitting sufficient heat and pressure to be generated to cause an ignition of the main charge. This conclusion was based upon successful ignition of the two charges with larger diameters. It was concluded that sufficient information had been gained from the concrete block tests and to proceed to field tests in an oil shale bed at the Geokinetics oil shale test facility at Kamp Kerogen.

Test \# 3 was the first test to be fired in the ground. Four holes, 4 inches in diameter and 10 feet deep were drilled in an outcropping oil shale bed. The layout of the holes is shown in Figure 4. The holes were in a line, 13 feet apart. Hole 3SH1 contained a 4-pound tool, hole 3OB1 was an open observation hole, hole 3SH2 contained a 1-pound tool, and hole 3SH3 had a 3-pound tool. The observation hole was cased to 5 feet. 
Hole 3 SH2 was fired first. The surface above the hole bounced, and gas was emitted from the observation well. Hole $3 \mathrm{SH} 1$ was ignited next and was a misfire. Hole $3 \mathrm{SH} 3$ was then fired. The surface bounced, and gas was emitted from the observation well.

Air injection tests were carried out at the observation well before and after the shots. Two postshot core holes were drilled to a depth of 12 feet. The core holes were cased to 5 feet, and air injection tests were run on the core holes and the observation well. The core was examined and logged.

In test \#4, four tools were fired in the oil shale bed at a depth of 30 feet. A total of seven holes were drilled preshot, as shown in Figure 6. Four of the holes were shot holes, and three were observation holes. The shot holes were 5 inches in diameter, uncased, and the observation holes were cemented in place, and the holes were cemented to the surface. As shown in Figure 6, four tools were emplaced, one in each shot hole, as follows :

1. Shot hole 4SH1. 3.1 pounds of propellant. The propellant was 12 inches long, $2 \frac{1}{2}$ inches in diameter, in a steel casing with a slot in the bottom. Ignition was at the bottom.

2. Shot hole 4SH2. 6.1 pounds of propellant. The

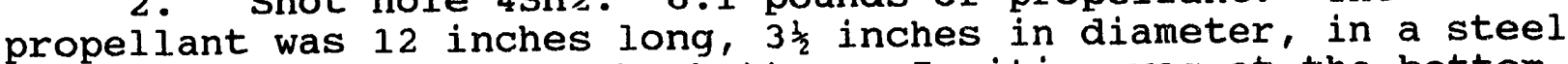
casing with the slot on the buttom. Ignition was at the bottom.

3. Shot hole 4SH3. 6.5 pounds of propellant. The propeliant was 24 inches long, $2 \frac{1}{2}$ inches in diameter, in a steel casing, with the slot 12 inches from the bottom. Ignition was 12 inches from the bottom.

4. Shot hole 4SH4. 6.2 pounds of propellant. The propeliant was 24 inches long, $2 \frac{1}{2}$ inches in diameter, in a steel casing, with the slot on the bottom. Ignition was on the bottom.

The test was fired on February 9, 1990. All holes fired. In shot $4 \mathrm{SH} 2$, the first ignitor did not fire the charge. The backup ignitor was activated and the charge fired. Following each shot, air injection tests were run on the adjacent observation holes. Seven postshot core holes were drilled, one core hole 3 feet from each shot hole and observation hole. Casing was set at 20 feet in the core holes. Air injection tests were run on the seven core holes and three observation holes. The cores were examined and logged.

In test \#5, it was planned to fire three shots at a depth of 60 feet. The holes were located about 80 feet apart, to eliminate overlapping effects of the shots. The location of the holes is shown in Figure 7. The thrte shot holes were drilled 8 
inches in diameter, and the three observation holes were 4 inches in diameter. The shot holes were cased to a depth of 30 feet, and the observation holes were cased to 20 feet. The charges were 6,12 , and 25 pounds. The tools were emplaced at 60 feet in two of the holes, but the hole for the 25-pound charge was obstructed at a depth of 32 feet. The tool was emplaced at 30 feet, just below the bottom of the casing. The tools were cemented in place, and the holes were cemented to the surface. The charges were fired sequentially. Air injection tests were run on the three observation holes preshot and postshot. Four postshot core holes were drilled, one core hole 13 feet from each shot hole and one core hole 3 feet from the 25-pound charge. All cores were examined and logged. Air injection tests were run on the four core holes and three observation holes.

Test \#6 was intended to fire a large charge of 60 pounds at the same depth as the 25-pound charge in test \#5 and to fire two shots simultaneously as an additional test. However, due to a shortage of funds, the simultaneous shot was not carried out, and the emplacement holes were converted to observation holes for the single shot test. No core holes were drilled in this test.

\section{OBSERVATIONS AT SHOT TIME}

\section{Test \#1}

Four charges, 2 inches in diameter and 6 inches long, with various configurations of casing and horizontal slots, were encased in concrete blocks 2 feet in diameter and 3 feet long. Charges 1 and 3 were misfires. Charges 2 and 4 fired. Both shots had the same effect upon the concrete cylinders. The cylinders were shattered, and large fragments were scattered over an area with a radius of 80 feet. The fragments ranged in size from 3 to 10 cubic inches. Most of the fragments were large. The base of the cylinders remained in place as a cone with the apex of the cone at the base of the tool. In the case of tool $\# 2$, the base of the tool remained in place on the apex of the cone. The sides of the cone sloped at approximately 45 degrees from the centerline of the cylinder.

\section{Test \#2}

Three smaller charges, $\frac{1}{2}$ inch to $\frac{1}{4}$ inch in diameter and 3 inches long, were emplaced in concrete cylinders 2 feet in diameter and $2 \frac{1}{2}$ feet long. All three ignitors fired but failed to ignite the main propellant charge. The energy of the ignitors cracked the cylinders and slightly displaced the pieces along the crack. 
Test \#3

This test, and all subsequent tests, were fired in holes drilled into the oil shale bed. The test layout consisted of three shot holes, 10 feet deep, and one observation hole, 11 feet deep. See Figure 4 for details of the test layout.

Shot hole $3 \mathrm{SH} 1$ was a misfire. It was concluded that the misfire was due to moisture leaking into the tool.

Shot hole $3 \mathrm{SH} 2$ was fired. A strong surface bounce was observed over the shot hole, and water and gas were blown out of the observation hole, 13 feet distant. A prominent fracture was created on the surface as shown in Figure 5.

Shot hole 3 SH3 was fired. A strong surface bounce was observed over the shot hole, and a small amount of gas was vented from the observation hole, 27 feet distant. The fracture created by the previous shot was extended 15 feet, and 2 new fractures were formed. There was spalling of the surface rock around the collar of the shot hole.

Test \#4

The test layout consisted of four shot holes and three observation holes. The shot holes were 30 feet deep, and the observation holes were 35 feet deep. Figure 5 gives the layout of the holes, and the details of the design and energy yield of the tools. A camcorder was used to record surface effects at shot time. A flash bulb at each shot was wired to fire at the time of ignition.

Shot hole $4 \mathrm{SH} 1$. No surface bounce was observed. The camera vibrated strongly. There was a strong blow of gas out of 4OB1. No gas emanated from $4 O B 2$. The flash fired at the same time as the shot.

Shot hole 4SH2. The first ignition did not fire. The backup ignitor was activated, and it fired the shot. The flash fired on the first ignition try. A good surface bounce was observed. The camera vibrated strongly. Gas was vented from $4 O B 2$ and $40 B 3$ (4OB1 was capped). The venting of gas from 4OB3 was remarkable, as this hole was 60 feet distant from the shot hole.

Shot hole 4SH3. A strong surface bounce was observed. The camera vibrated strongly. There was no visible blow of gas out of $40 B 3$. However, there was enough gas to blow a paper plug out of the casing. Holes $4 O B 1$ and $4 O B 2$ were capped. There was a delay of one second between the flash and the shot. This indicates a delay between the firing of the ignitor and the full 
ignition of the main charge. This was the tool with center ignition.

Shot hole 4SH4. No surface bounce was observed. The camera vibrated strongly. There was a strong blow of water and gas out of $4 \mathrm{OB} 3$. There was no delay between the flash and the shot.

\section{Test \#5}

The test layout consisted of three shot holes and three observation holes. Two of the shot holes were 60 feet deep, with the tools emplaced at the bottom. The third shot hole was drilled 60 feet deep, but because of an obstruction in the hole, the shot was emplaced at 30 feet. The observation holes were 65 feet deep. Figure 7 gives the layout of the holes and the details of the design and energy yield of the tools. The three shot holes were approximately 80 feet apart, at the apexes of a triangie. The wide separation was used to avoid interacting fracturing effects between individual shots. A camcorder was used to record the shots. There were no flash bulbs.

Shot 5SH2 was fired first. This was a 6-pound tool at a depth of 60 feet. There was no surface bounce. There was no camera vibration. A solid column of water was blown out of the adjacent observation hole followed by a jet of gas. The other observation holes did not vent water or gas.

Shot hole 5SH3 was the next shot. This was 12 pounds at 60 feet. Prior to the shot, there was 33 feet of water in the observation hole. There was a slight surface bounce and some camera vibration. The observation hole vented a strong plume of gas and water 40 feet into the air. After the water was unloaded from the hole, the hole vented gas strongly.

Shot hole 5SH1 was the third shot. This was 25 pounds at 30 feet. There was a strong surface bounce, estimated at 3 inches maximum uplift. The camera vibrated strongly. The cement collar of the shot hole had three radial cracks. There was a strong blow of gas out of the observation hole and a weak venting of gas from 5OB2 at a distance of 80 feet.

Test \#6

The test consisted of one shot hole and three observation holes. The shot was 60 pounds at 30 feet. See Figure 8 for the test layout. Two camcorders were used to record the shot. One camera was 100 feet from the shot, and the other was at 200 feet. There were no flash bulbs. The closest observation hole, at a distance of 13 feet, was a 4-inch hole cased to 20 feet with 2 inch casing. The next hole, at the distance of 26 feet, was an $8 \frac{1}{2}$-inch open hole. There was a strong surface bounce, estimated at 6 inches maximum uplift. The camera at 100 feet showed strong 
vibration, and the camera at 200 feet showed very little vibration. A very strong blow of gas was vented from $60 \mathrm{~B} 1$ and $60 B 2$. There was no venting of gas from 6OB3, at a distance of 106 feet from the shot. The forceful venting of gas from holes $60 B 1$ and $60 B 2$ was followed by dense black smoke billowing slowly from the holes.

\section{OBSERVATIONS DURING CORE DRILLING}

A total of 13 postshot core holes were drilled. The purpose of the holes was to examine the nature of the shot-induced fractures and to provide injection holes for the air injection tests.

The following core holes were drilled:

$\begin{array}{ll}\text { Test \#3 } & 2 \text { holes } \\ \text { Test \#4 } & 7 \text { holes }\end{array}$

one hole 3 feet from each shot hole

one hole 3 feet from each shot hole, one hole 3 feet from each observation hole; holes adjacent to the observation holes were 10 to 20 feet from the closest shot holes

Test \#5 4 holes

one hole 13 feet from each shot hole, one hole 3 feet from shot hole $5 \mathrm{SH} 1$ ( 25 pounds at 30 feet)

Test \#6 none

All cores were taken using a split-tube core barrel. With this type of core barrel, the tube containing the core is opened along its longitudinal axis, exposing the core with a minimum disturbance of the core.

In most cases, there was little obvious evidence of shotinduced fractures. An exception was core hole 5C4, which was located 3 feet from the 25-pound shot. This hole had a zone of broken shale 3 inches wide at the shot level, four 45-degree fractures within $2 \frac{1}{2}$ feet above this zone, and another 45-degree fracture one foot below the zone. In the other six holes drilled 3 feet from the shots, there were horizontal fractures parallel to the bedding planes at the shot level that appeared different from the normal bedding plane partings. Usually, there were two or three fractures within a 2-inch interval, and in some cases vertical cross-breaking between these fractures.

In the six holes that were located 10 feet or farther from the shot holes, there was, in every case, a horizontal break within one foot of the shot level. However, it was not possible 
to clearly differentiate these fractures from the natural bedding plane partings.

\section{OBSERVATIONS DURING AIR INJECTION TESTS}

Air injection tests were run at the four field tests. Figures 4 through 8 show the layout of the holes at each test site. Air tests were run on observation holes drilled preshot and in core holes drilled postshot. The air tests in the observation holes were run preshot and postshot. In all, air tests were run on 18 holes. No postshot air tests were run in the shot holes as these were plugged with cement.

In the shot holes, the tool was emplaced at the bottom, and the hole was cemented to the surface. The observation holes and core holes had casing cemented to a depth of 5 feet in the 12foot holes, 20 feet in the 35-foot holes, and 30 feet in the $65-$ foot holes. The well heads were fitted with equipment for running air tests.

Air was provided by a compressor rated at 185 standard cubic feet per minute (scfm) at 100 pounds per square inch pressure (psi). Air flow rates were measured using a 2-inch Gerrard Venturi tube flowmeter with readout on an oil manometer. Representative curves of air injection rate as a function of pressure are given in Figures 9 to 22 . The data are summarized in Table 2 .

Test \#3

This was the first firing of a propellant charge in the ground. Preshot, there was zero permeability at 90 psi pressure in hole 3OB1. Postshot, the hole was very permeable, taking $160 \mathrm{scfm}$ at $15 \mathrm{psi}$. The twc core holes, $3 \mathrm{Cl}$ and $3 \mathrm{C2}$, showed even greater permeability, taking $121 \mathrm{scfm}$ at $15 \mathrm{psi}$. There was little difference in air injection rates when the adjacent holes were open or closed, indicating a high flow of air to the surface. This was probably due to the intersection of a shot-induced horizontal fracture with a vertical fracture 8 feet distant, as shown in Figure 5 .

\section{Test \#4}

See Figure 6 for the layout of test holes. There were four shot holes, three observation holes, and seven postshot core holes, drilied to depths of 30 to 35 feet. Air tests were run preshot and postshot in the observation holes and postshot in the core holes.

Preshot permeability was zero at $90 \mathrm{psi}$ in $40 \mathrm{OB} 1$ and $40 \mathrm{OB} 2$. There was slight preshot permeability in $40 B 3$. 
The first shot was 3.2 pounds in shot hole 4SHl. After the shot, observation hole 4OB1, 13.5 feet distant, showed good permeability of $92 \mathrm{scfm}$ at $30 \mathrm{psi}$. Observation hole 4OB2, 45 feet distant, showed no increase in permeability.

The second shot was 6.1 pounds in shot hole 4 SH2. At observation hole 4OB2, 20 feet distant, the flow was $59 \mathrm{scfm}$ at 30 psi.

The third shot was 6.2 pounds in shot hole 4 SH 3 . Observation hole 4OB3, 20 feet distant, had a natural permeability of $32 \mathrm{scfm}$ at $30 \mathrm{psi}$. This was increased to $64 \mathrm{scfm}$ by the shot.

The fourth and last shot was 6.2 pounds in shot hole $4 \mathrm{SH} 4$. Air tests were run at $4 O B 3$, which is midway between shot holes $4 \mathrm{SH} 3$ and $4 \mathrm{SH} 4$ and is the same hole that tested $64 \mathrm{scfm}$ after the third shot. The fourth shot increased its air flow to $120 \mathrm{scfm}$.

These shots and air tests were carried out on February 9 , 1990. Four months later, on June 8, 1990, seven core holes were completed, one hole located 3 feet from each shot hole and observation hole. Air tests were run on each of these holes and were repeated on the observation holes.

Core holes $4 \mathrm{Cl}$ and $4 \mathrm{C} 2$ had no permeability at $97 \mathrm{psi}$. Observation holes 4OB1, 3 feet from 4C2, was very permeable, taking $210 \mathrm{scfm}$ at $30 \mathrm{psi}$. This same hole, when tested four months earlier, after firing shot hole 4SH1, took only $92 \mathrm{scfm}$. During injection into 4OB1, air flows were noted at all holes except 4C6. Hole $4 \mathrm{C7}$ blew a continuous spray of water. It is believed that the increased permeability of $40 B 1$ was caused by the fracture from shot hole $4 \mathrm{SH} 2$, and the lack of permeability in $4 \mathrm{Cl}$ and $4 \mathrm{C2}$ was caused by plugging of the fracture by cuttings from drilling the core holes.

Core hole $4 \mathrm{C} 3$, located 3 feet from shot hole $4 \mathrm{SH} 2$, showed good permeability, taking 100 scfm at 30 psi.

Core hole $4 \mathrm{C} 4$ is adjacent to $4 \mathrm{OB} 2$ and midway between shot holes $4 \mathrm{SH} 2$ and $4 \mathrm{SH} 3$. The permeability was low at $34 \mathrm{scfm}$. The adjacent observation hole 4OB2, which had good permeability when tested 4 months earlier, had very low permeability.

Core hole $4 \mathrm{C} 5$ is adjacent to shot hole $4 \mathrm{SH} 3$. It showed good permeability taking $128 \mathrm{scfm}$. There was little change in air intake when the other holes were open or closed.

Hole $4 \mathrm{C6}$ is adjacent to $40 \mathrm{OB} 3$ and midpoint between shot holes $4 \mathrm{SH} 3$ and $4 \mathrm{SH} 4$. This hole showed low permeability at $38 \mathrm{scfm}$. Whereas the adjacent observation hole 4OB3 had much greater permeability at $100 \mathrm{scfm}$. When $40 B 3$ was tested four months 
earlier, immediately after the shot in $4 \mathrm{SH} 4$, the permeability was much less at $62 \mathrm{scfm}$. This increase in permeability in later tests is difficult to explain. Perhaps the repeated air injections in the various wells in Test \#4 opened up the fracture adjacent to the well bore.

Hole $4 \mathrm{C7}$ is 3 feet from shot hole $4 \mathrm{SH} 4$. Hole $4 \mathrm{C7}$ showed good permeability at $108 \mathrm{scfm}$. This hole has an inflow of water from the formation. The inflow of air as a function of pressure is erratic when adjacent holes are closed but becomes linear when the adjacent holes are opened. Holes 4 OB 3 and $4 \mathrm{C} 6$ are adjacent holes 15 feet from $4 \mathrm{C7}$. When air is injected into $4 \mathrm{C7}$, the outflow from $4 \mathrm{C6}$ is much greater than the outflow from $40 B 3$. However, when air is injected into 4OB3 and 4C6,4OB3 takes more air than $4 \mathrm{C} 6$.

\section{Test \#5}

See Figure 8 for the layout of the test holes. The shot holes were located at the apexes of a triangle, approximately 80 feet apart. The wide separation was to avoid interaction between the shots, such as occurred in Test \#4, where the shots were 26 to 40 feet apart.

Shot hole 5SH1 was 25 pounds at 30 feet, shot hole 5 SH2 was 6 pounds at 60 feet, and shot hole 5 SH 3 was 12 pounds at 60 feet.

All of the observation holes were pressured preshot. All three holes took a small flow of air at 45 to $50 \mathrm{psi}$. Wells $50 B 1$ and 5OB2 had a slight intercommunication. After all three shots were fired, the observation holes were air tested. Hole 5OB1 gave reproducible results in four injection tests, as shown in Figure 18. However, holes 5OB2 and 5OB3 were erratic in repeated tests. The inability to reproduce the test results in these holes is believed to be due to water in the fracture at the depth of 60 feet. The firing of the shots and initial air tests were done on September 3, 1990. After core drilling, on February 9, 1991, air tests were again run on the three observation holes and also on the four core holes. During the testing of the holes adjacent to shot hole 5SH1, the compressor broke down. These tests were completed on April 2, 1991.

Observation hole 5OBl, with all holes closed, had less permeability than when tested five months earlier. Air flows had decreased from $254 \mathrm{scfm}$ to $144 \mathrm{scfm}$. There was a large increase in air flow when the two adjacent core holes were opened, indicating excellent communication between these holes. These tests were repeated two months later, on April 2, 1991, with similar results (see Figure 20). Observation holes 5OB2 and $50 B 3$ had results similar to the earlier tests. 
Core hole 5C4, which was three feet from the shot point, showed slightly less permeability that core hole $5 \mathrm{Cl}$ and observation hole 5OB1, both of which were 13 feet from the shot point. All three holes showed excellent permeability and intercommunication with each other, as indicated by the increase in flow rates upon opening the adjacent holes shown in Table 3 .

Table 3. Air Injection at Holes Adjacent to 25-Pound Shot

Air Injected, scfm

\begin{tabular}{lllll} 
& \multicolumn{2}{c}{ Adjacent Holes Closed } & \multicolumn{2}{c}{ Adjacent Holes open } \\
\cline { 2 - 5 } Hole & 15 psi & 30 psi & 15 psi & 30 psi \\
$50 B 1$ & 60 & 204 & 196 & 297 \\
$5 C 1$ & 60 & 166 & 132 & 244 \\
$5 \mathrm{C} 4$ & 68 & 150 & 136 & 264
\end{tabular}

\section{Test \#6}

See Figure 8 for the layout of the test holes. The four holes are in a line: 6OB1 13 feet from the shot hole, 6OB2 26 feet from the shot hole, and 6OB3 106 feet from the shot hole. The tool was the largest used in the program, 60 pounds at 30 feet.

Air was injected into $60 \mathrm{~B} 1$ at $116 \mathrm{scfm}$ at $15 \mathrm{psi}$. Although this demonstrates excellent permeability, it is slightly less than the air injected into the three holes adjacent to shot hole 5SH1, where the energy yield of the tool was less than one-half the yield of this shot. This indicates that we may have reached a limitation on the nearby effects on the formation related to energy yield, at a depth of 30 feet an a propellant weight of 25 pounds. If this is correct, increasing the weight at this depth above 25 pounds will not increase the permeability. This will give a limited powder factor of 1 pound per foot.

\section{CONCLUSIONS}

The following conclusions were drawn from the tests:

1. Oil shale at shallow depths was fractured with a propellant tool that was specifically designed to create a single horizontal fracture. The tool created horizontal fractures that extended at least 20 feet from the shot hole.

2. A firing system and ignitor that did not use blasting caps proved reliable in firing the tools. 
3. The horizontal fractures were identified in core holes drilled postshot. Some of the fractures were difficult to differentiate from natural bedding plane partings. Close to the larger charges, breakage and rubble were present. At farther distances, the break was relatively smooth and clean.

4. The fractures resulted in a very significant increase in the air permeability of the injection holes located at distances of 13 feet and 20 feet from the shot hole.

5. Holes drilled prior to fracturing show greater air permeability than holes drilled after fracturing. This is attributed to plugging of the fracture by drill cuttings.

6. Horizontal fractures were created at depths of 30 and 60 feet with a ratio of propellant to overburden thickness of as little as 0.1 pound per foot.

7. A transient surface uplift was noted on the larger charges and on the most shallow charges. In addition to a relationship to depth and energy, transient surface uplift was related to the cross-sectional area of the tool, which is a major factor in the rate of gas injection into the fracture.

\section{ACKNOWLEDGEMENTS}

The authors express their sincere appreciation to the U. S. Department of Energy for funding this work under cooperative agreement DE-FC21-86MC11076. Many people have contributed to this program, and the authors sincerely thank all.

\section{REFERENCES}

Lekas, M.A., J. M. Lekas, and F. G. Strickland, 1989. "Initial Evaluation of Fracturing oil shale with propellants for In Situ Retorting." Laramie, Wyoming, DOE Report DOE/MC/11076-2766. 


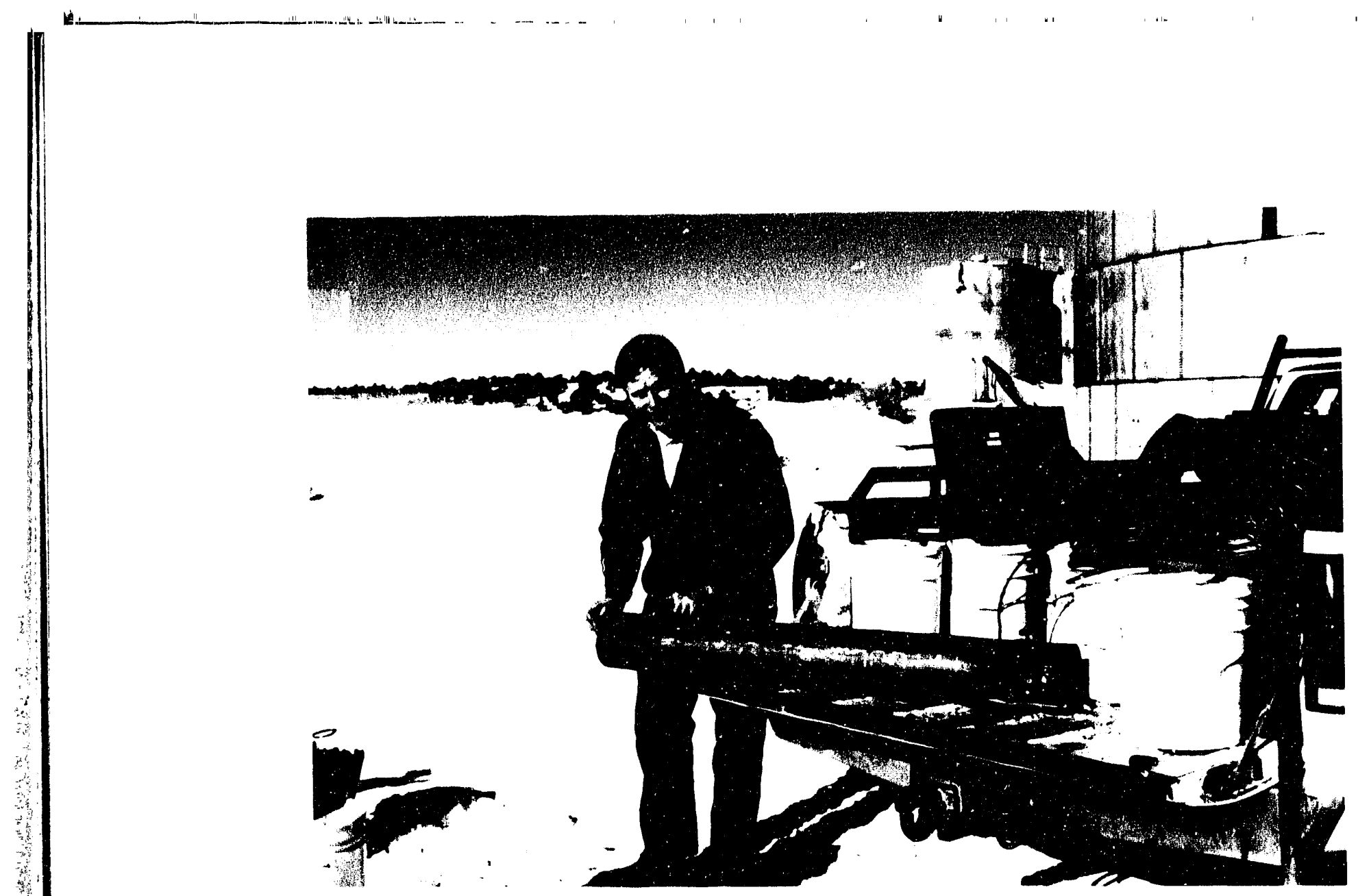

Figure 1. 60-pound propellant tool. Engineer is pointing to the horizontal gas emission slot at the bottom of the tool.

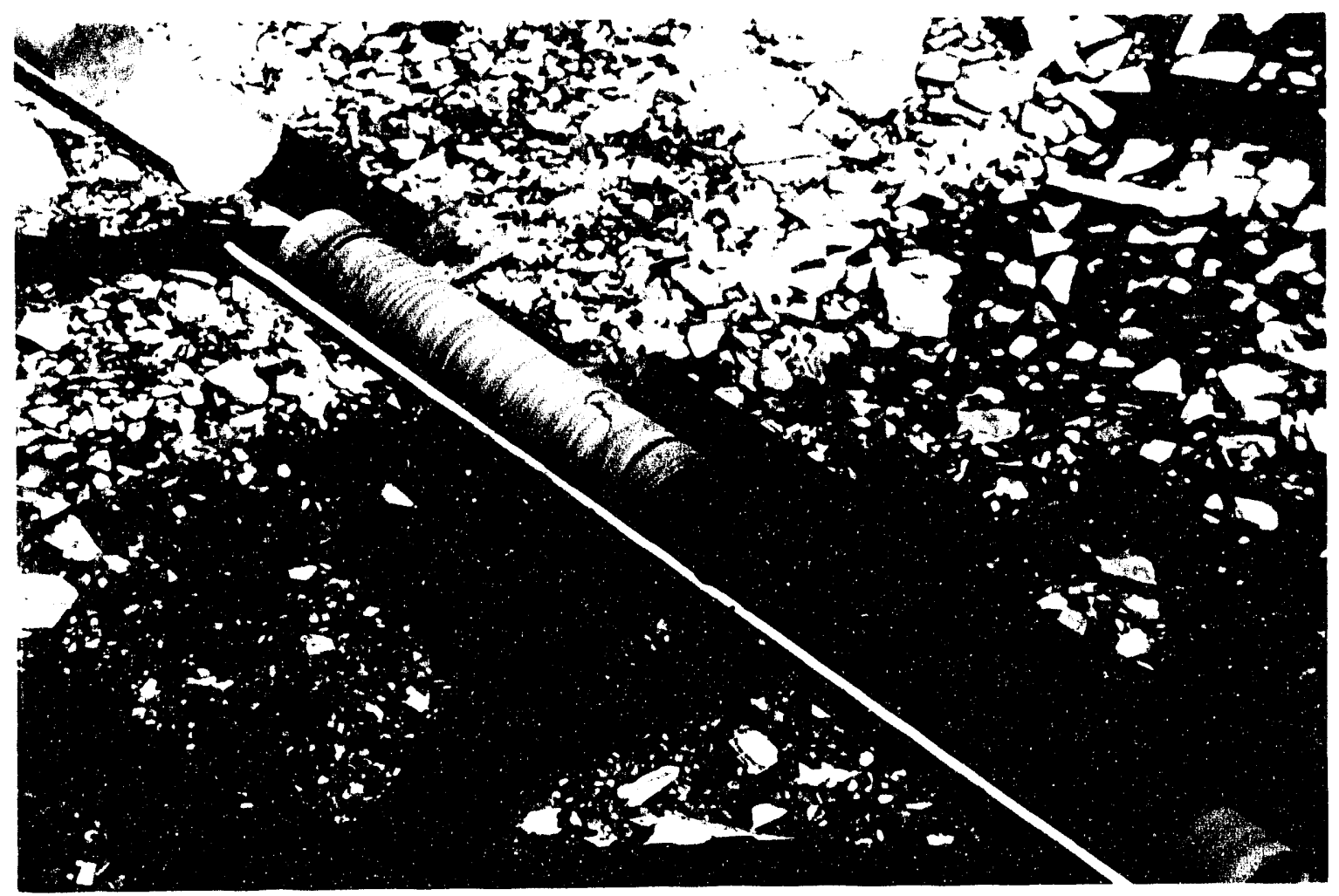

Figure 2. Shot-infuced horizontal fracture in postshot core. 


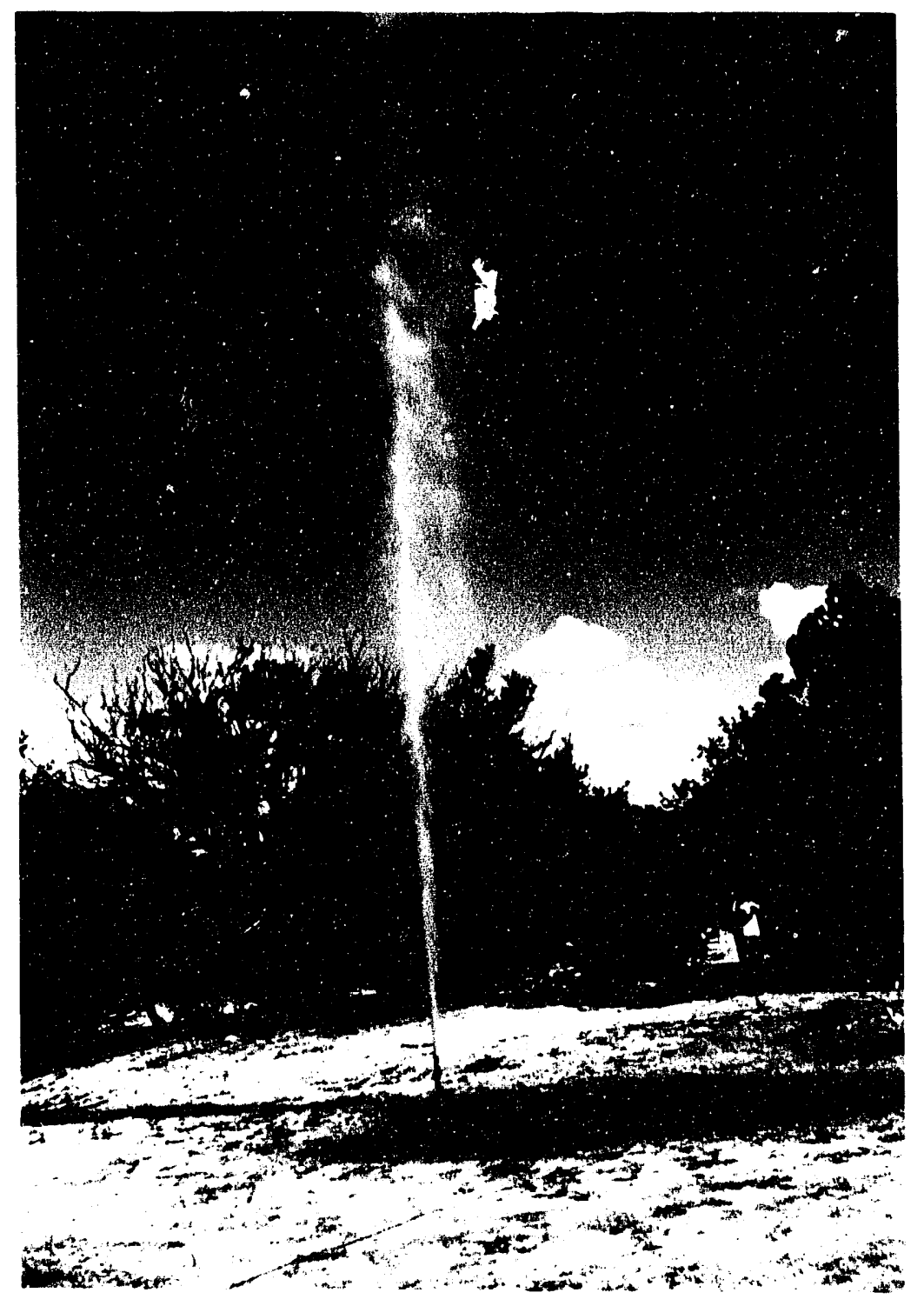

Figure 3. Water being ejected from observation hole at shot time. Propellant tool emplaced in hole 13 feet distant from observation hole. 
Table 1.

Summary of Tool Parameters

$\begin{array}{lllllll}\begin{array}{l}\text { Hole } \\ \text { Number }\end{array} & \begin{array}{l}\text { Weignt, } \\ \text { pounds }\end{array} & \begin{array}{l}\text { Length, } \\ \text { inches }\end{array} & \begin{array}{l}\text { Siameter } \\ \text { inches }\end{array} & \begin{array}{l}\text { Area, } \\ \text { square } \\ \text { inches }\end{array} & \begin{array}{l}\text { Loverburion } \\ \text { Thickness, } \\ \text { feet }\end{array} \\ 3 \mathrm{SH} 2 & 1 & 12 & 1.5 & 1.8 & \text { bottom } & 10 \\ 3 \mathrm{SH} 3 & 3 & 12 & 2.5 & 4.9 & \text { bottom } & 10 \\ 4 \mathrm{SH} 1 & 3.2 & 12 & 2.5 & 4.9 & \text { bottom } & 30 \\ 4 \mathrm{SH} 2 & 6.1 & 12 & 3.5 & 9.6 & \text { bottom } & 30 \\ 4 \mathrm{SH} 3 & 6.2 & 24 / 12 & 2.5 & 4.9 / 9.8 & \text { center } & 30 \\ 4 \mathrm{SH} 4 & 6.2 & 24 & 2.5 & 4.9 & \text { bottom } & 30 \\ 5 \mathrm{SH} 1 & 6.5 & 38 & 2.0 & 3.1 & \text { bottom } & 60 \\ 5 \mathrm{SH} 2 & 12.5 & 34 & 3.0 & 7.1 & \text { bottom } & 60 \\ 5 \mathrm{SH} 3 & 25 & 30 & 4.5 & 15.9 & \text { bottom } & 30 \\ 6 \mathrm{SH} 1 & 60 & 40 & 6.0 & 28.3 & \text { bottom } & 30\end{array}$


总至蒙

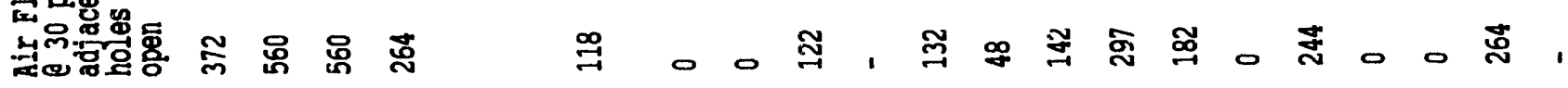

总容范

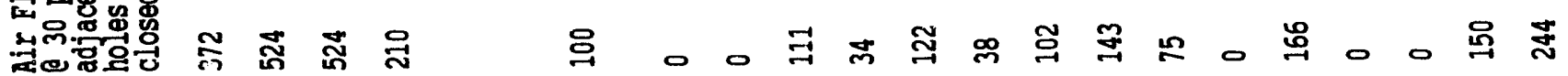

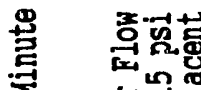

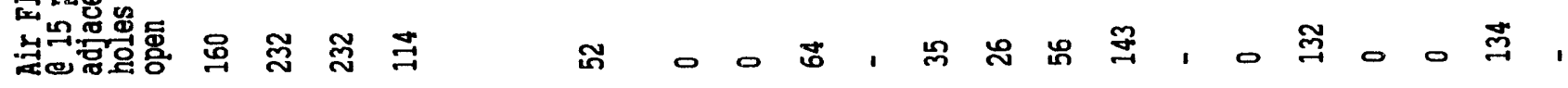

要

萝

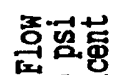

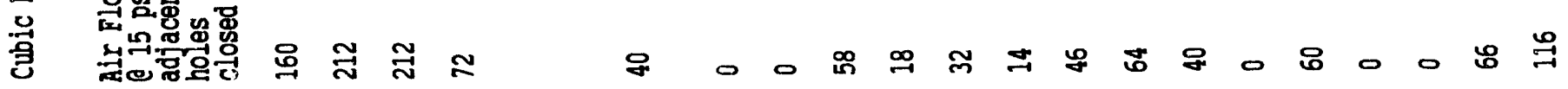

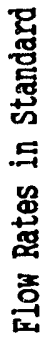

蛋

蕞

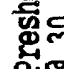

000000000000000000000

递获

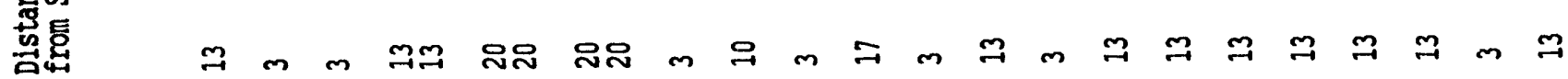

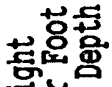

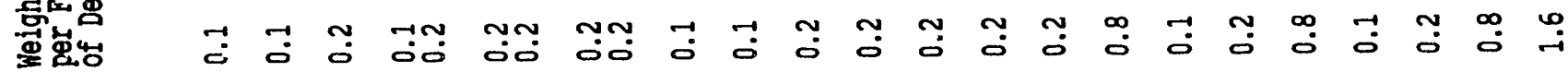

蒙.

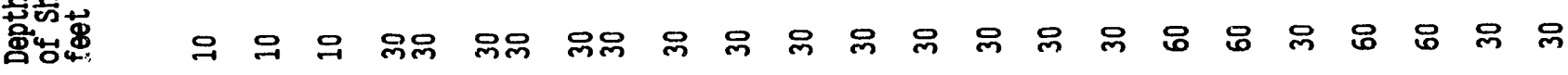
$\dot{a}$

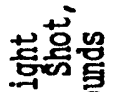

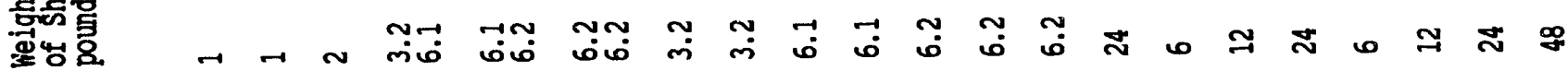

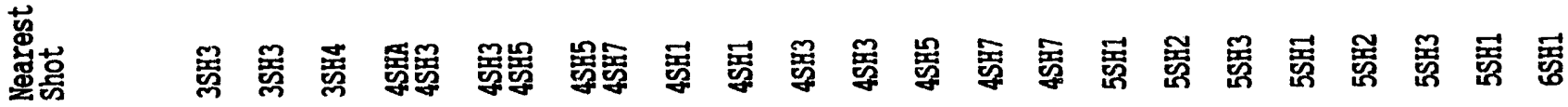

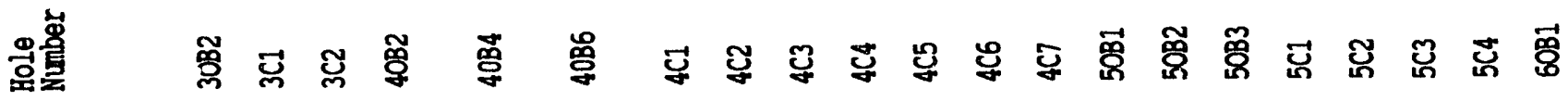




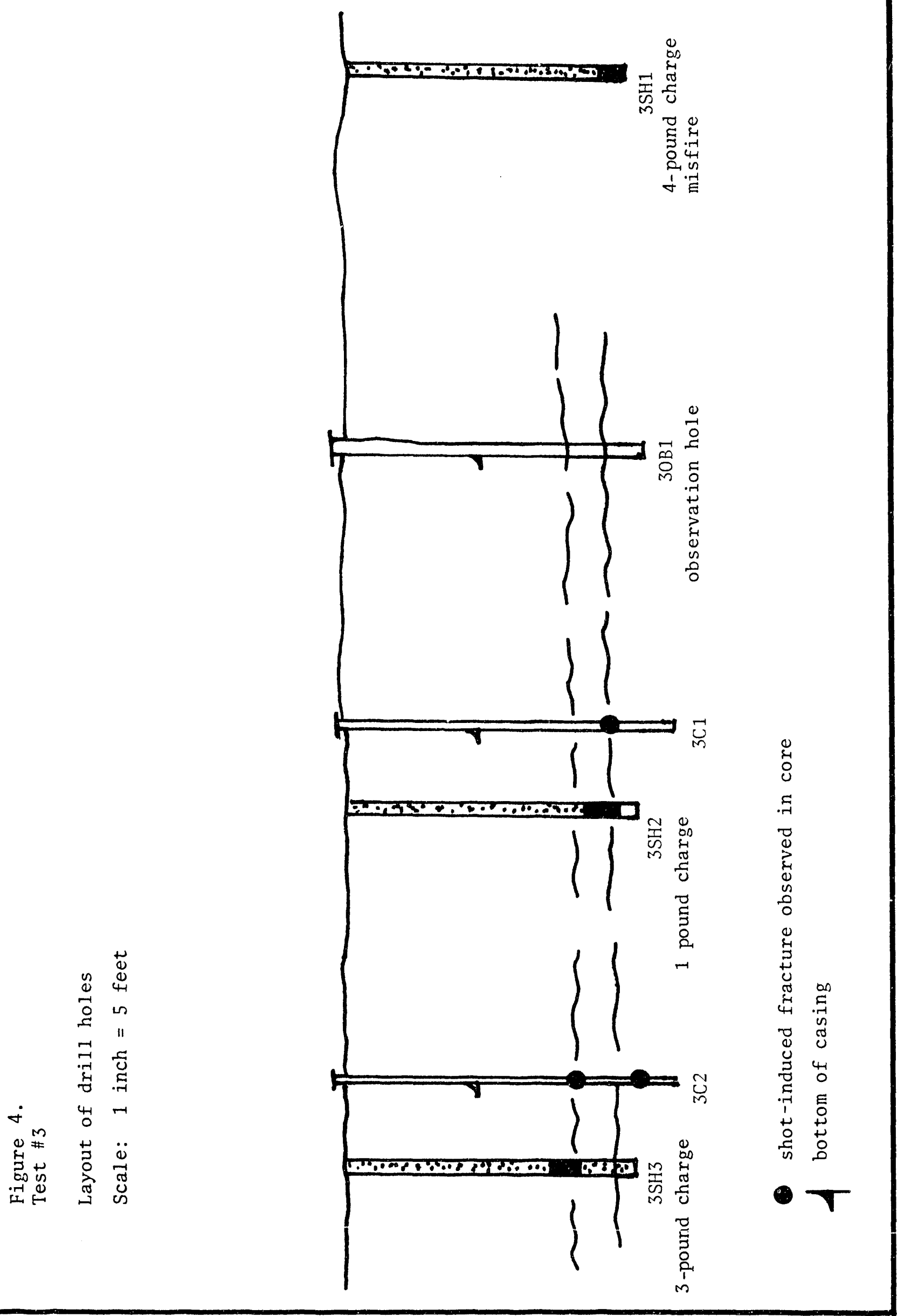



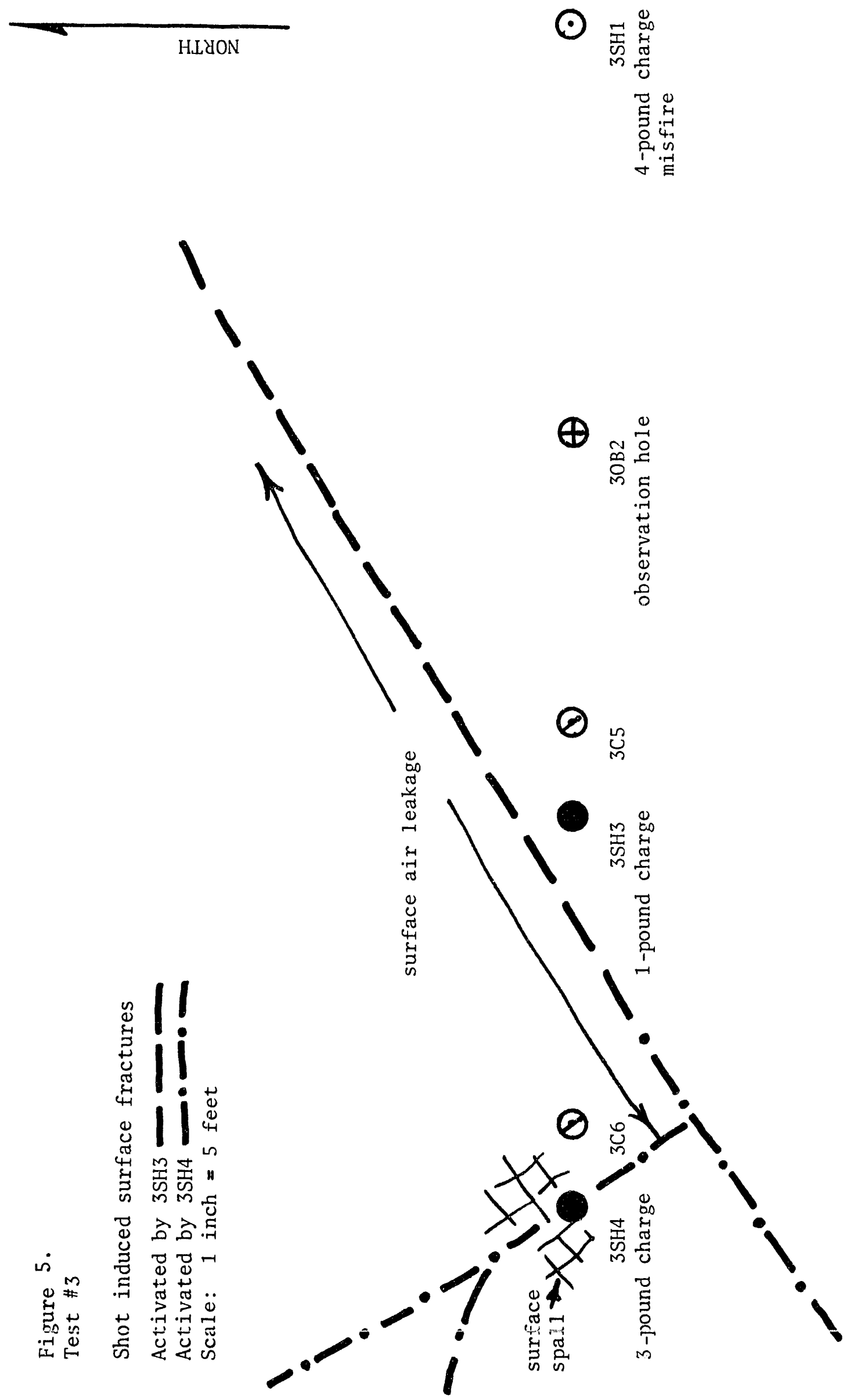


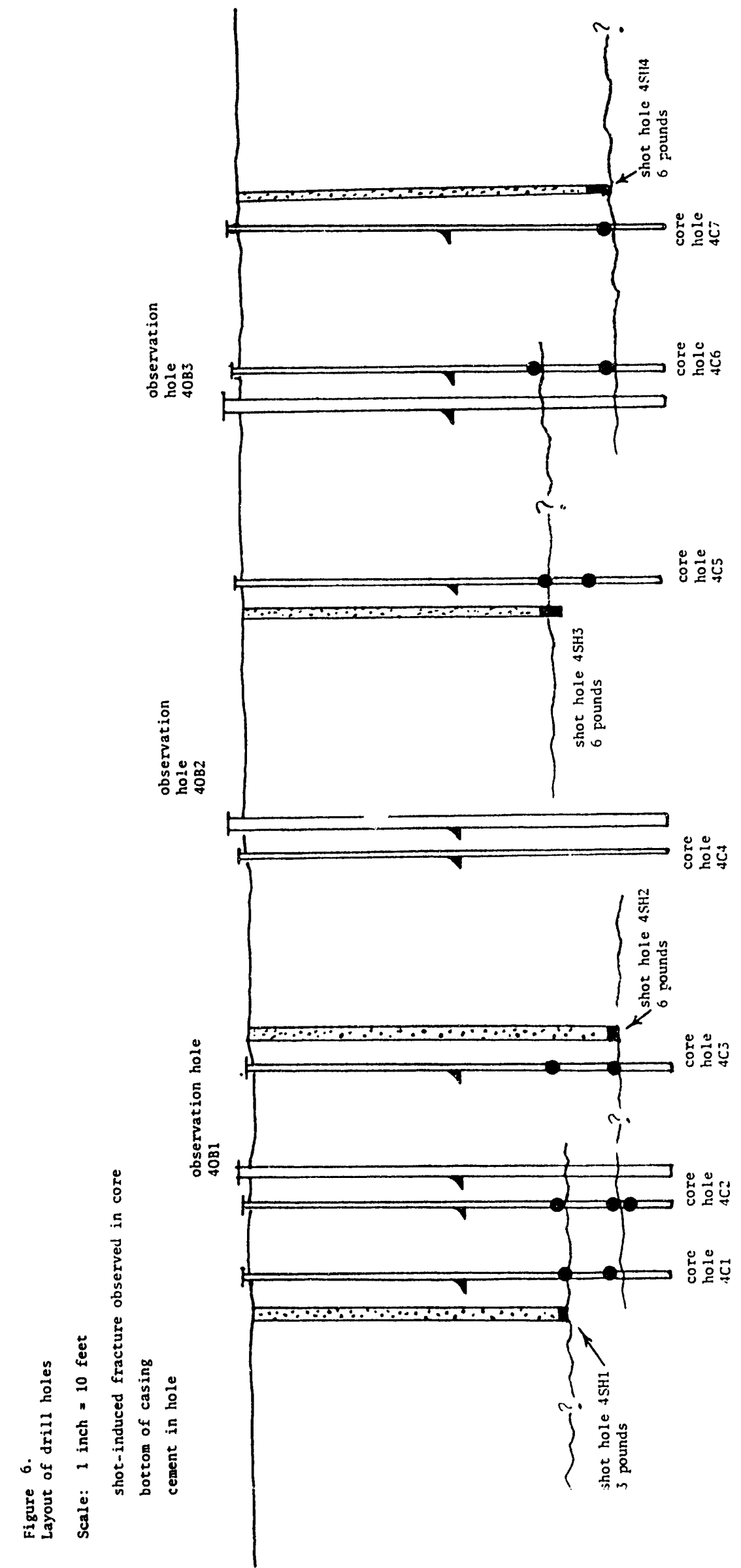




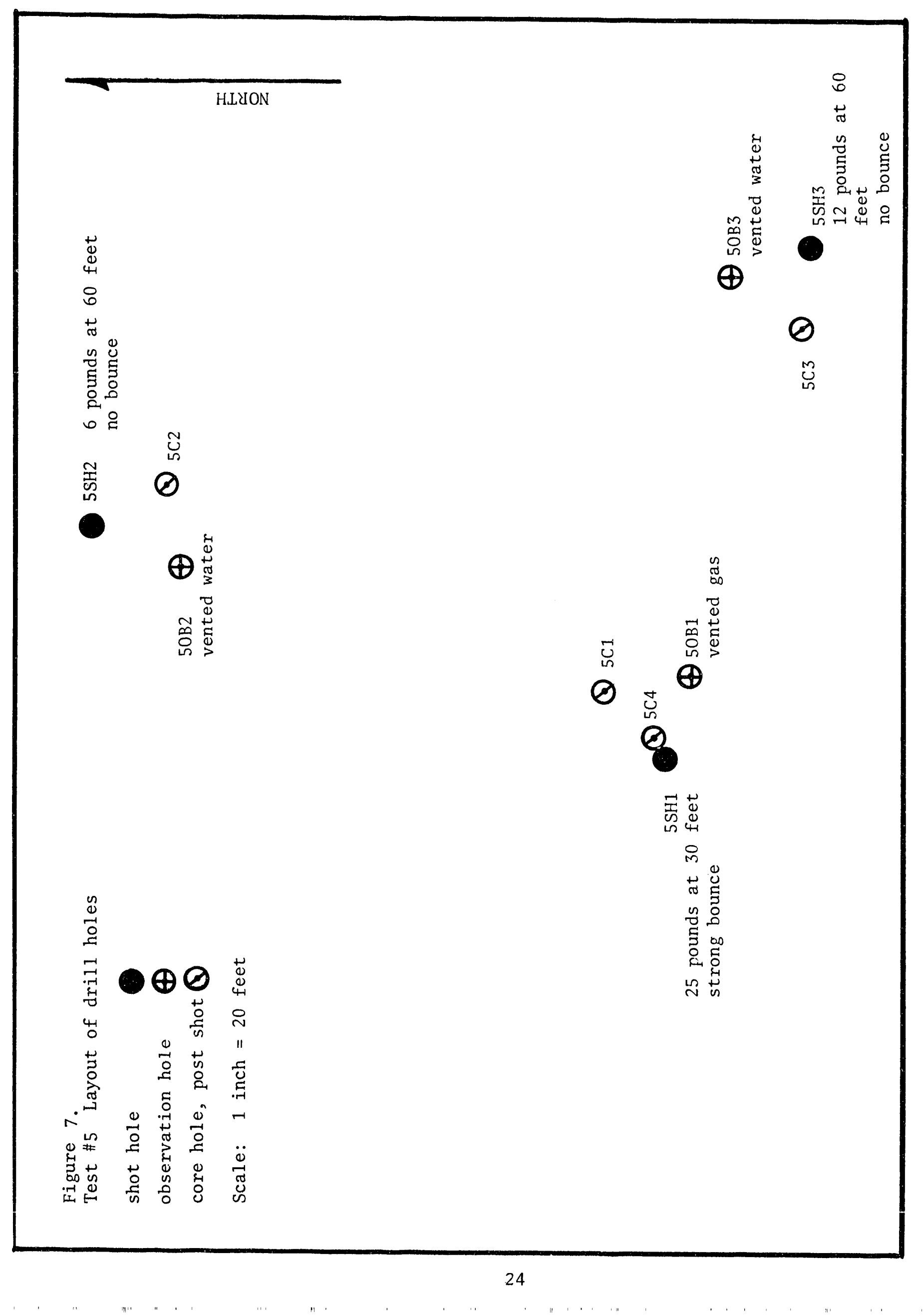




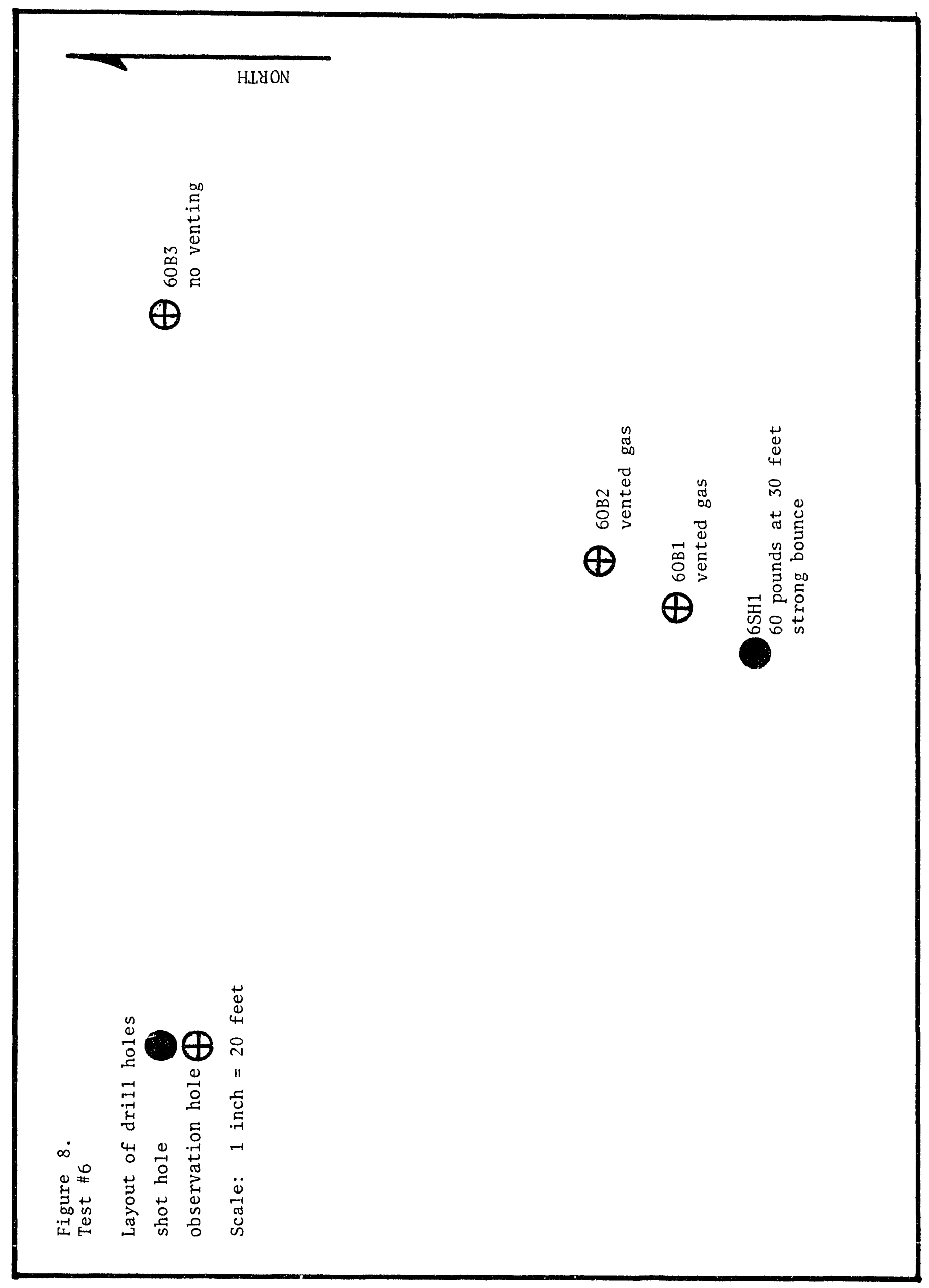




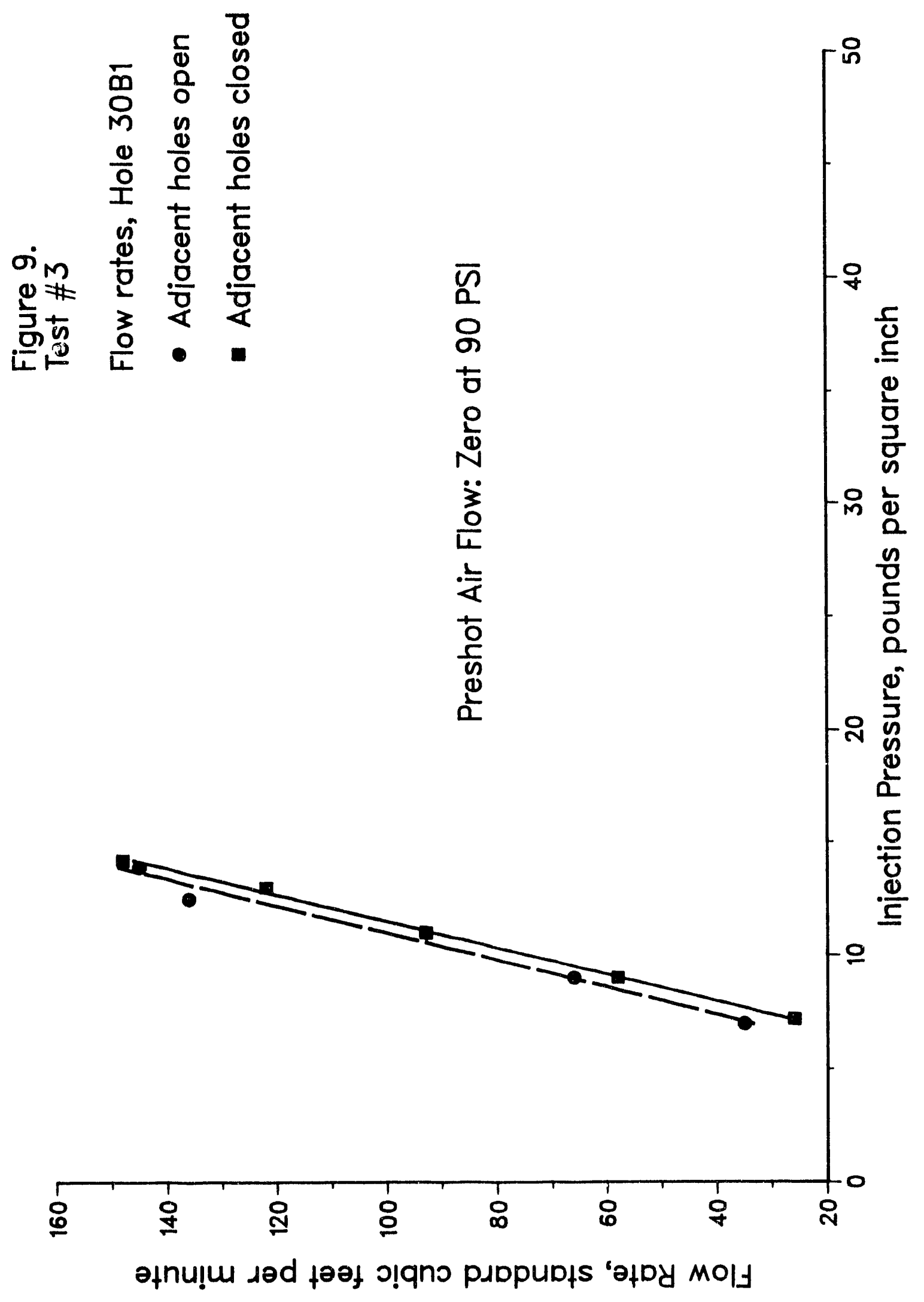




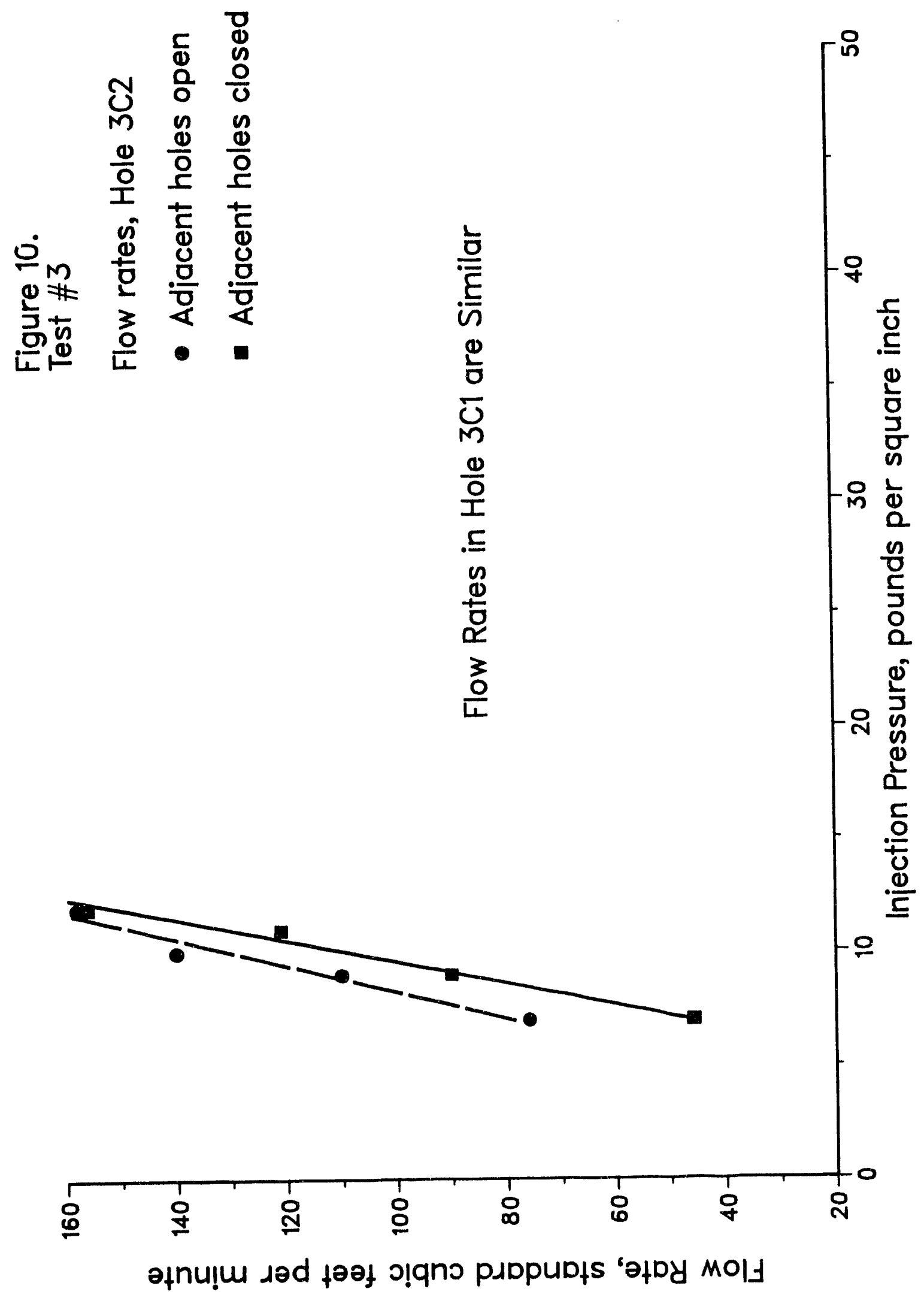




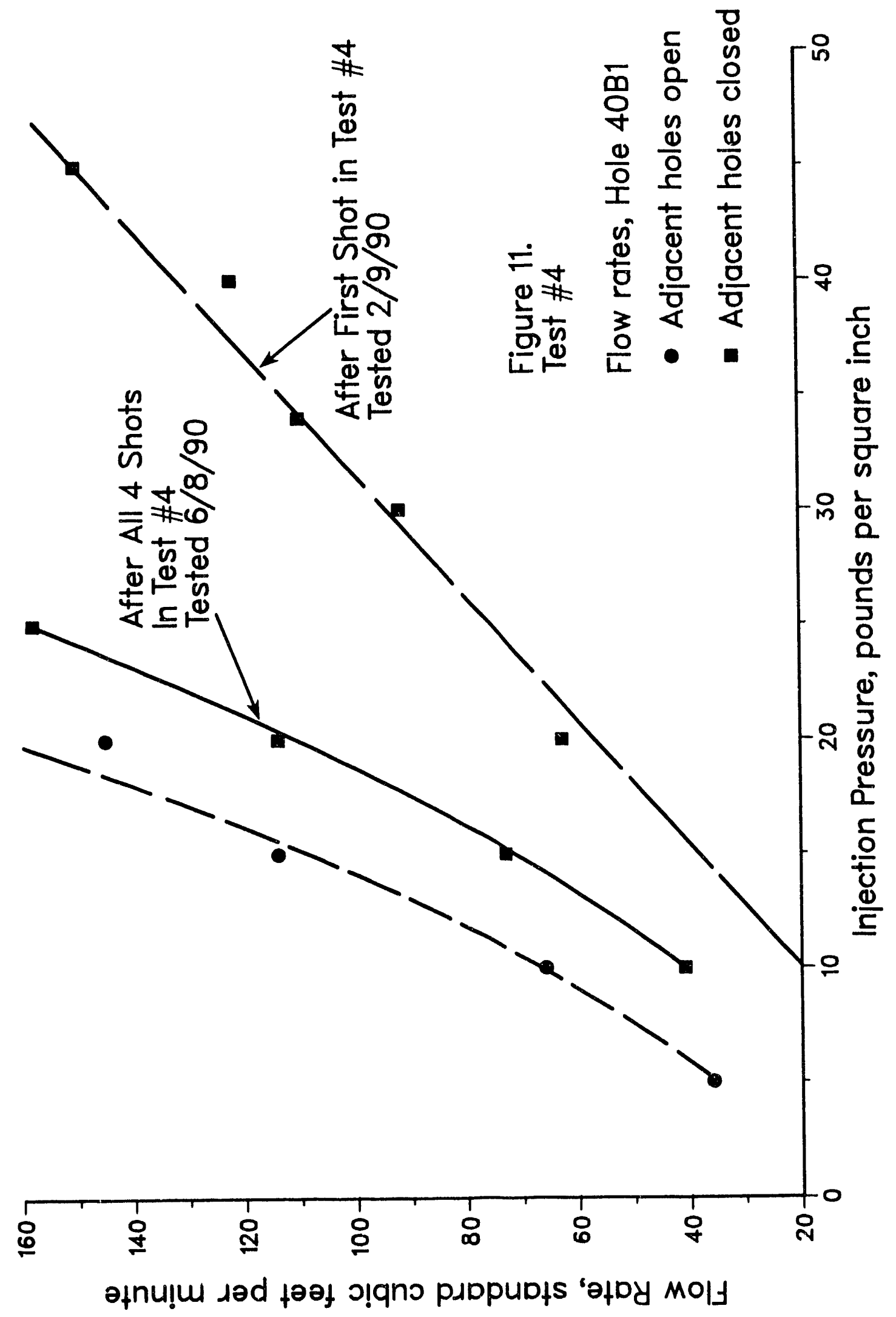




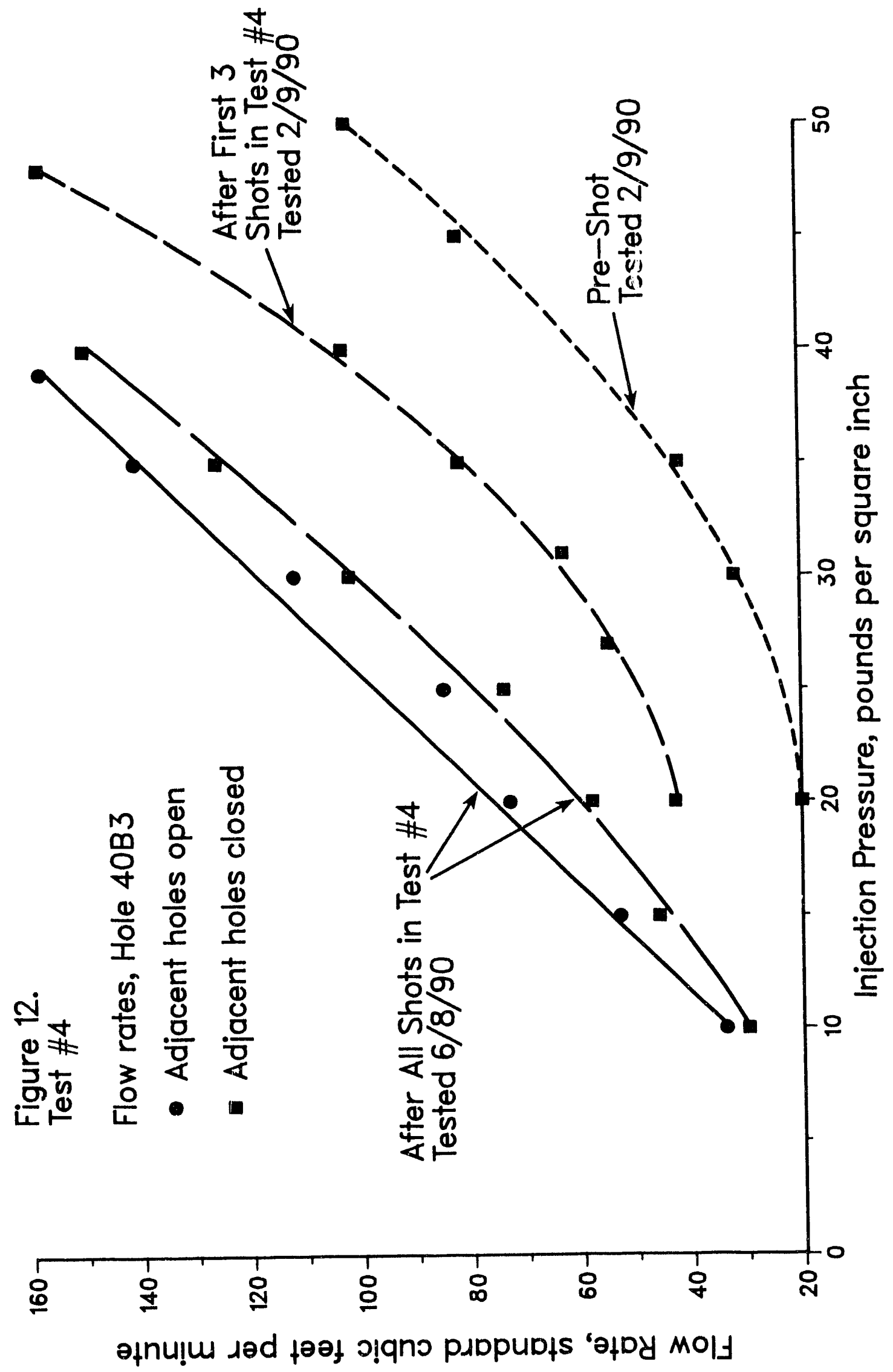




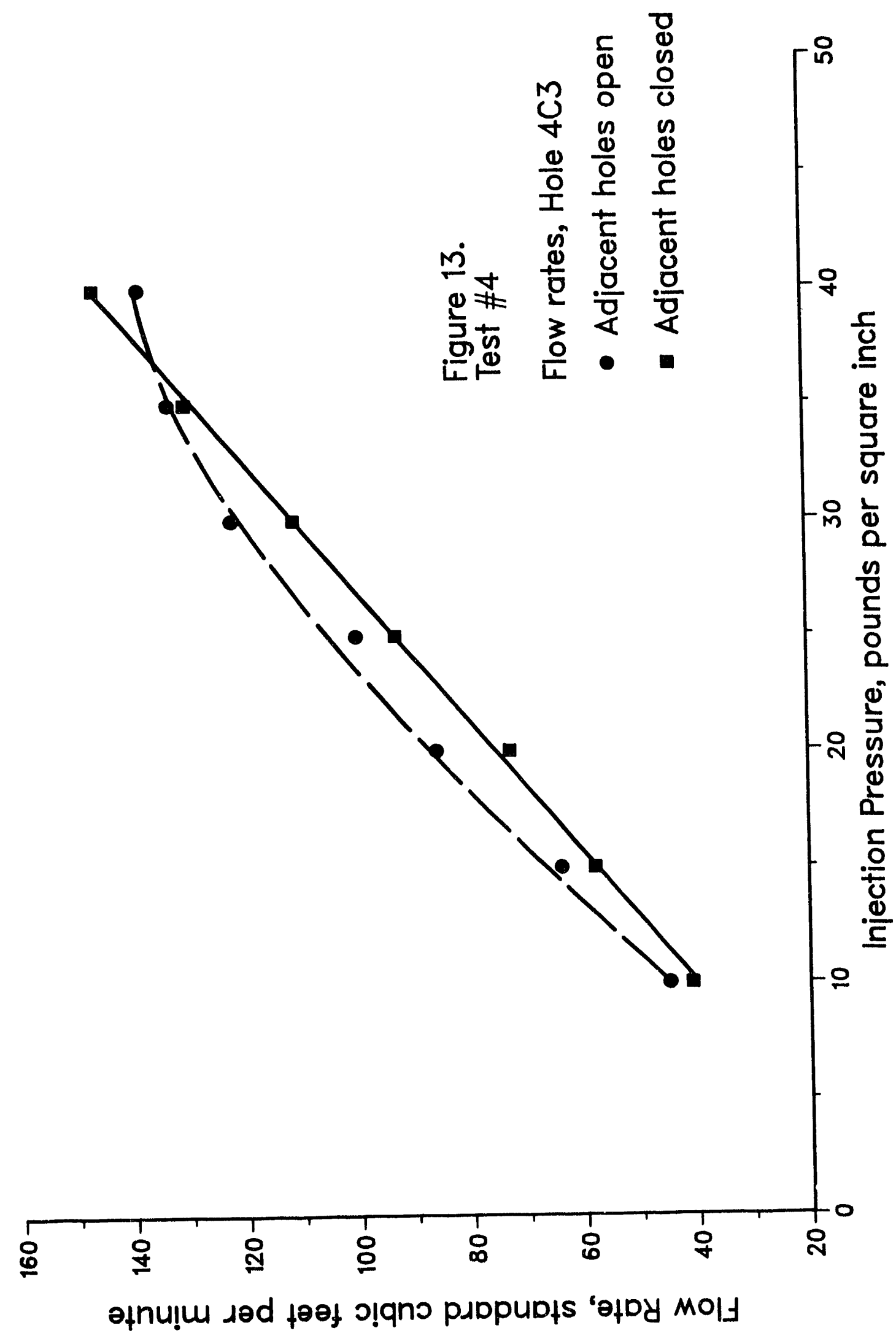




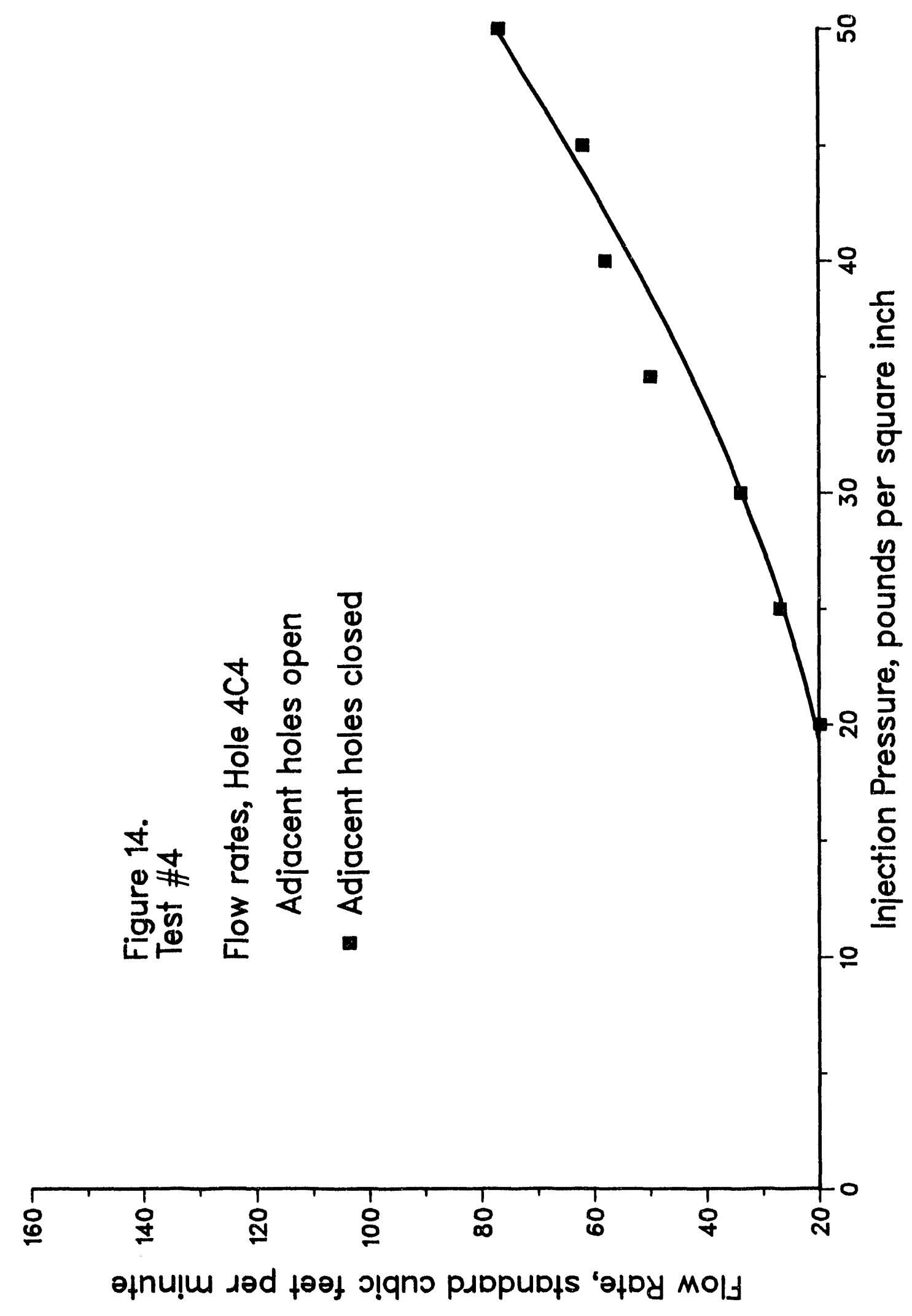




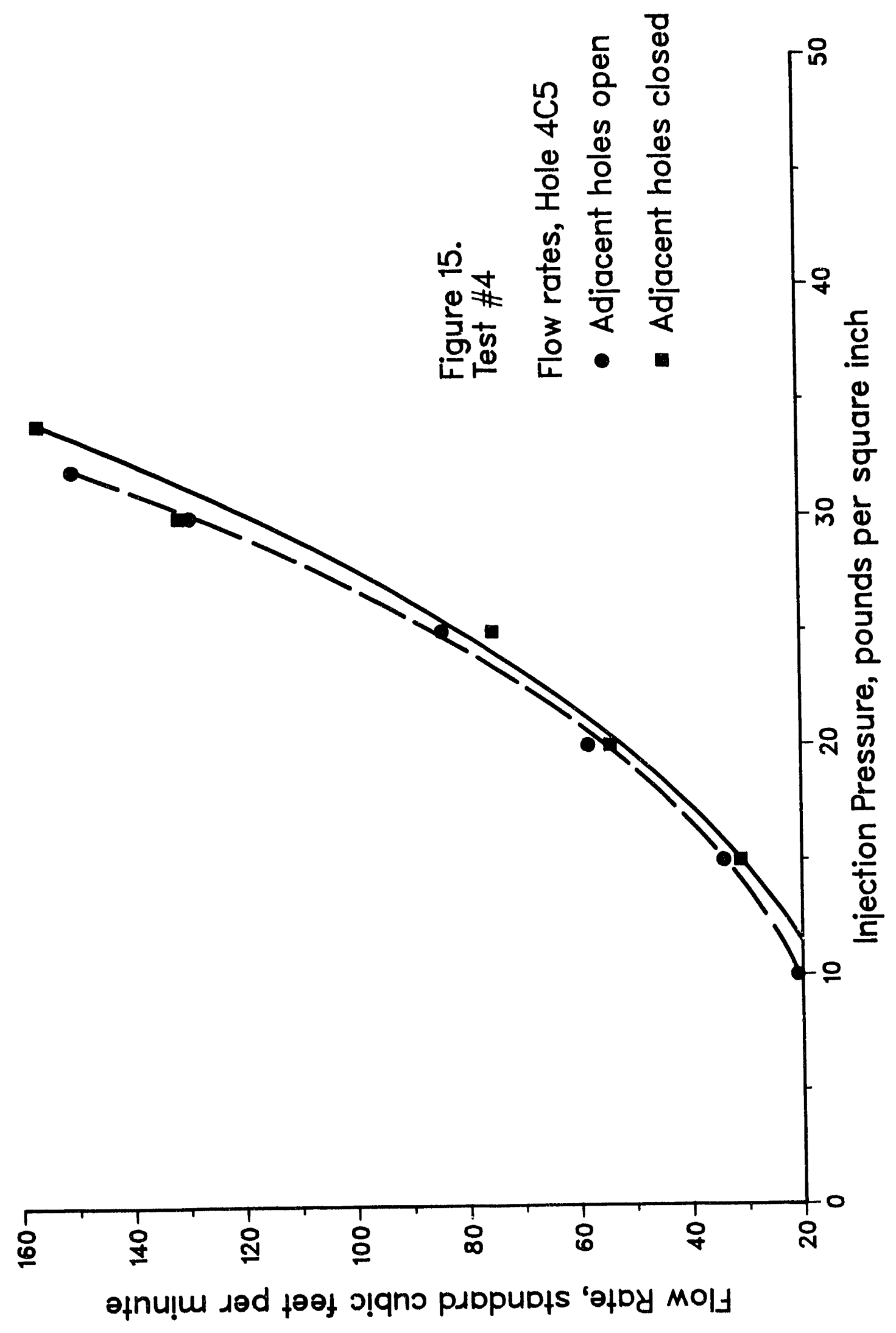




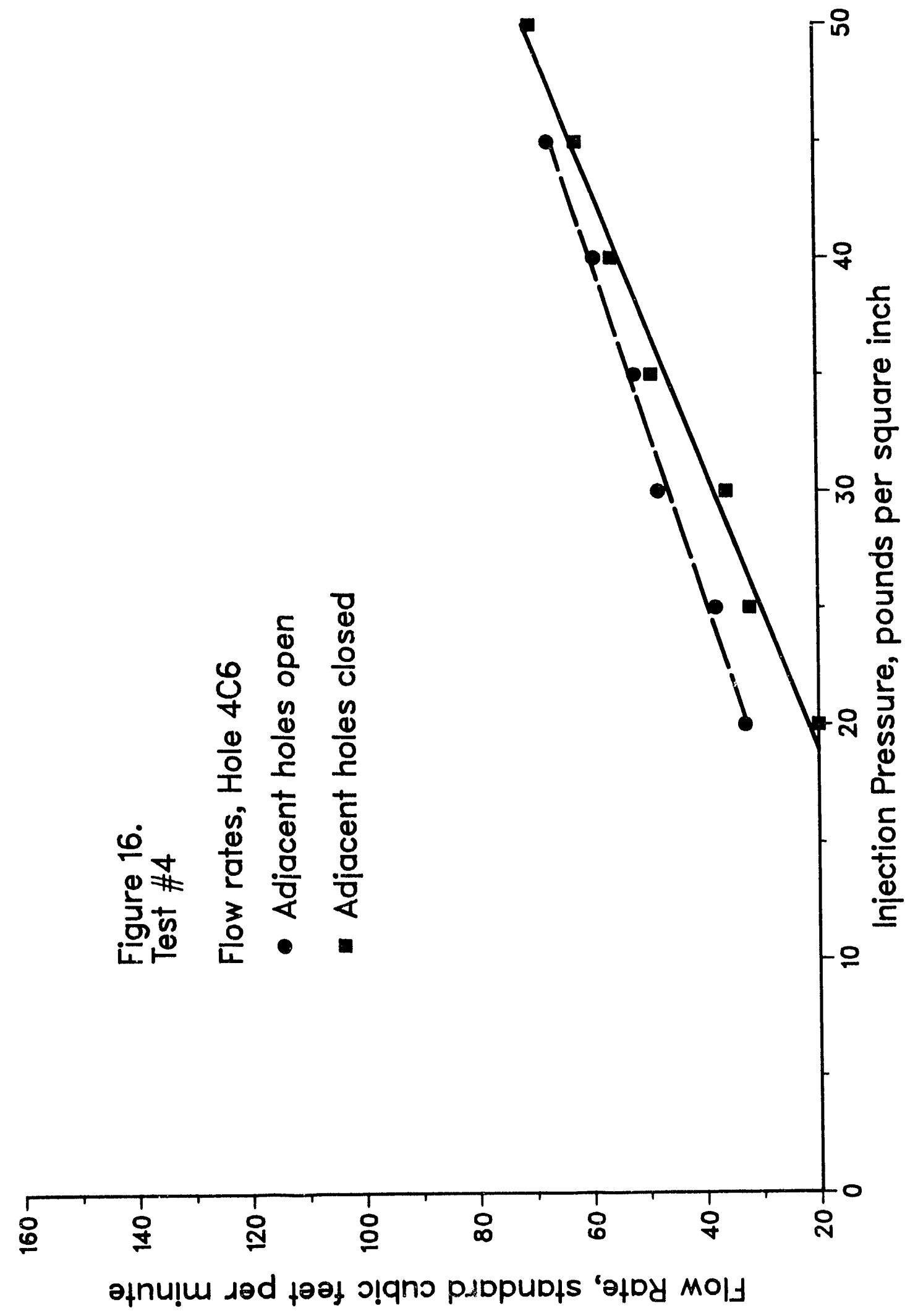




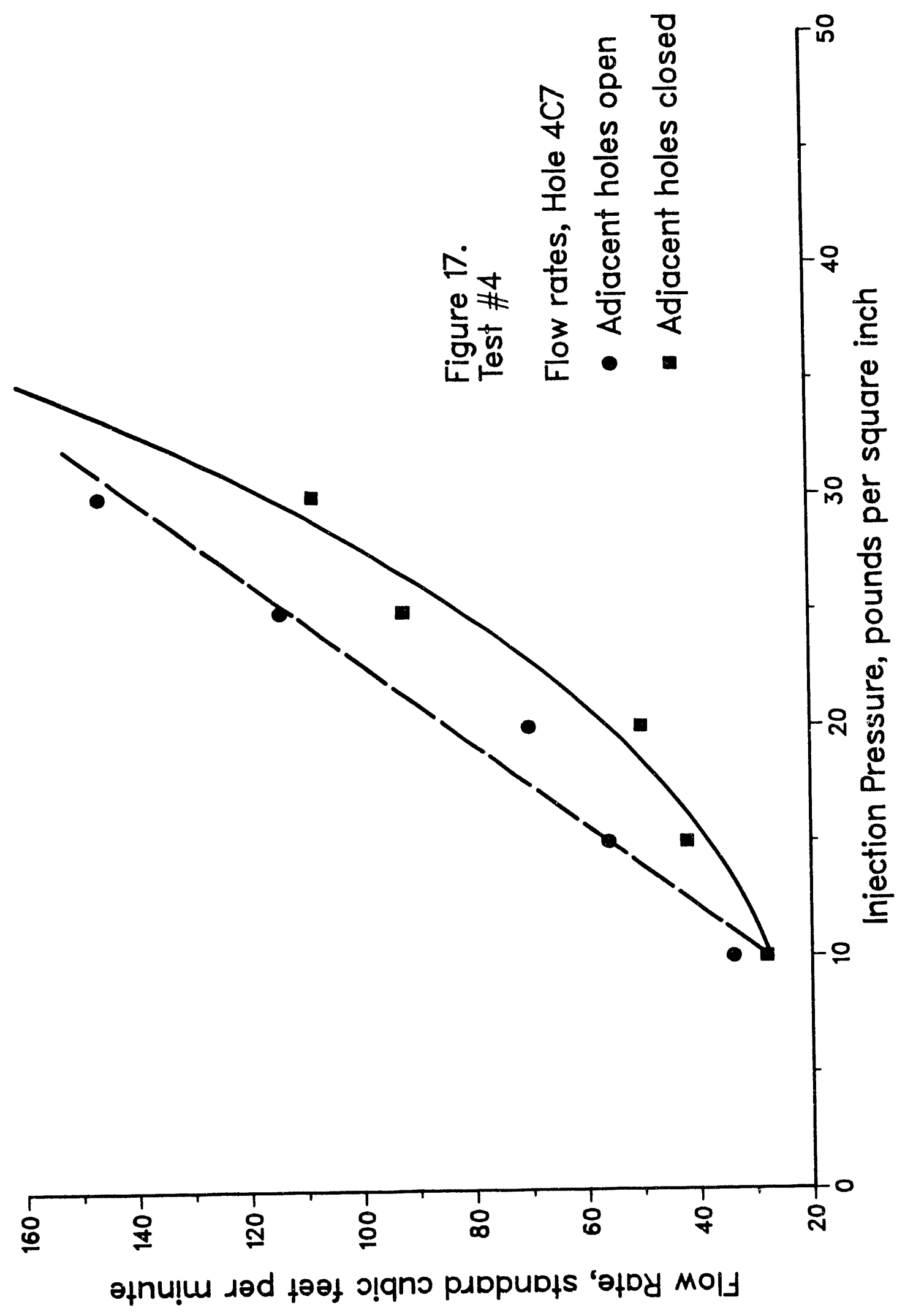




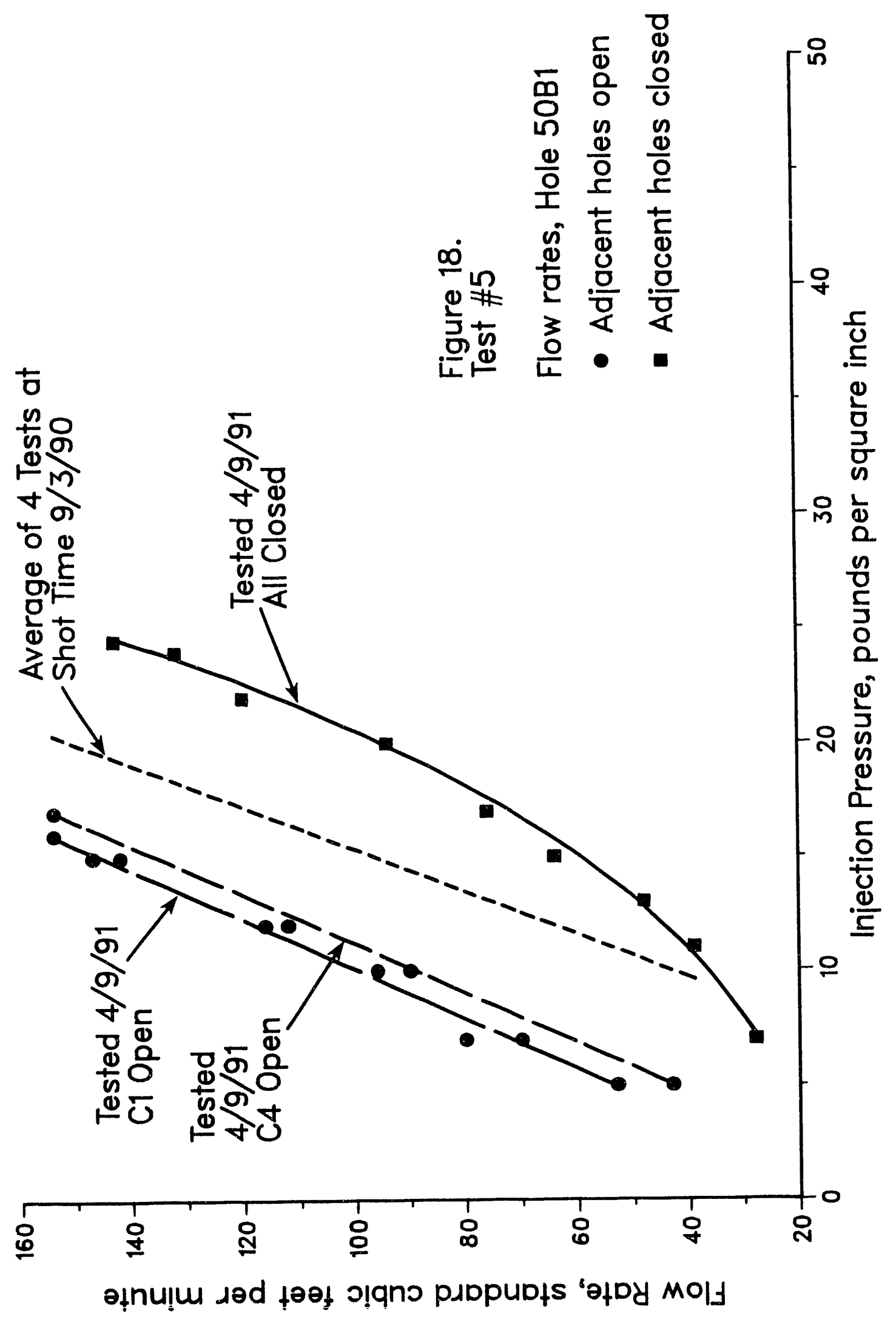




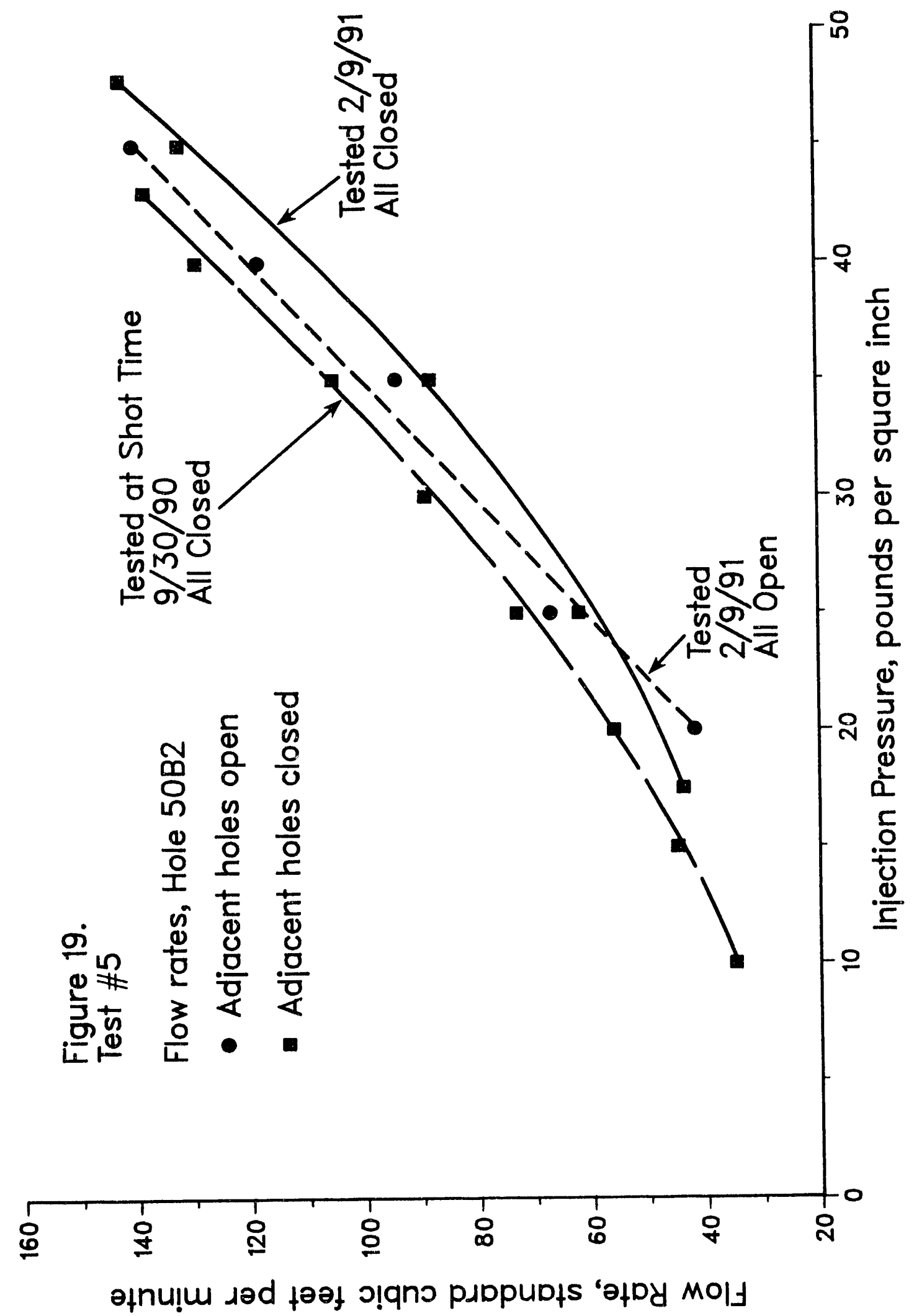




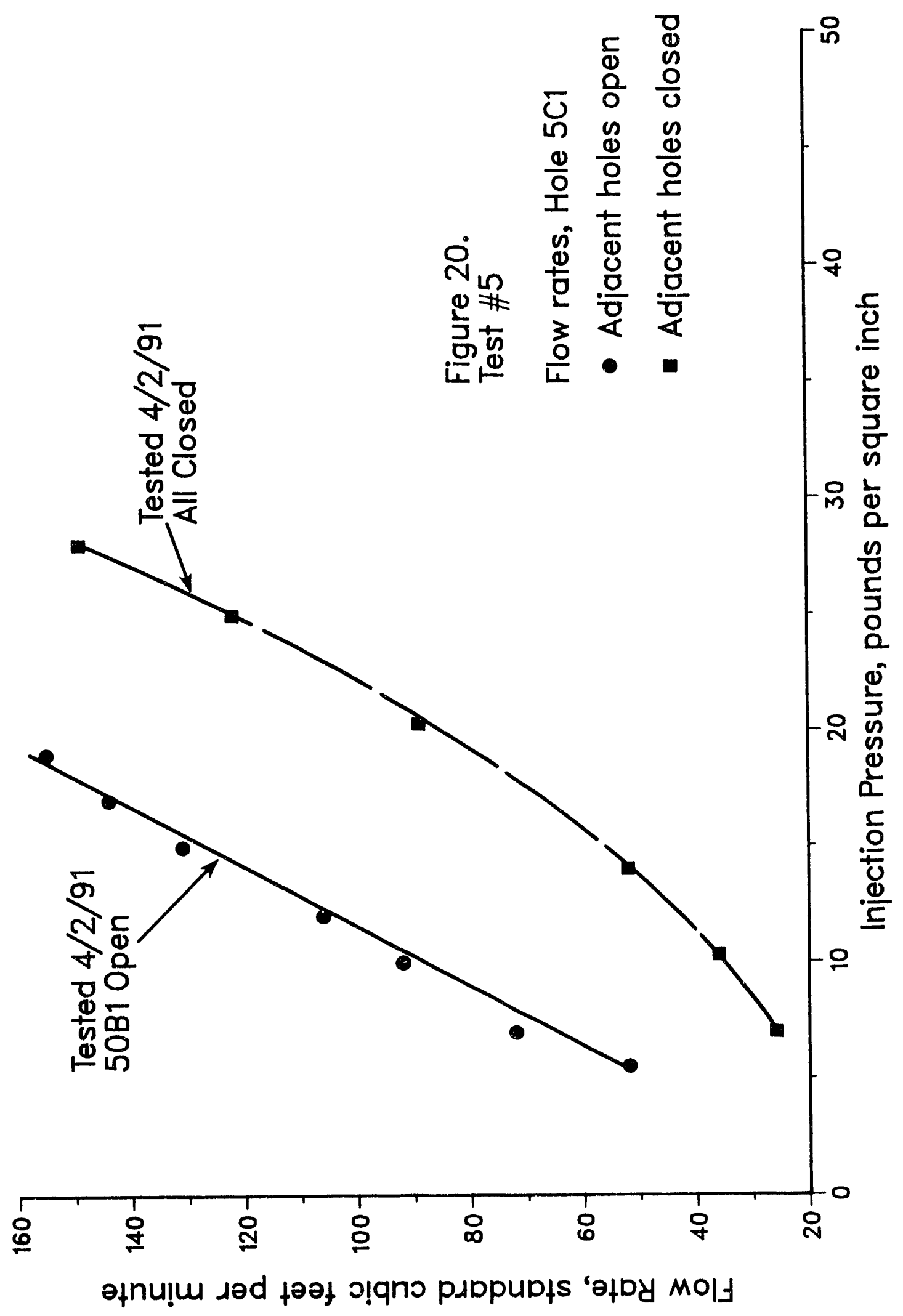




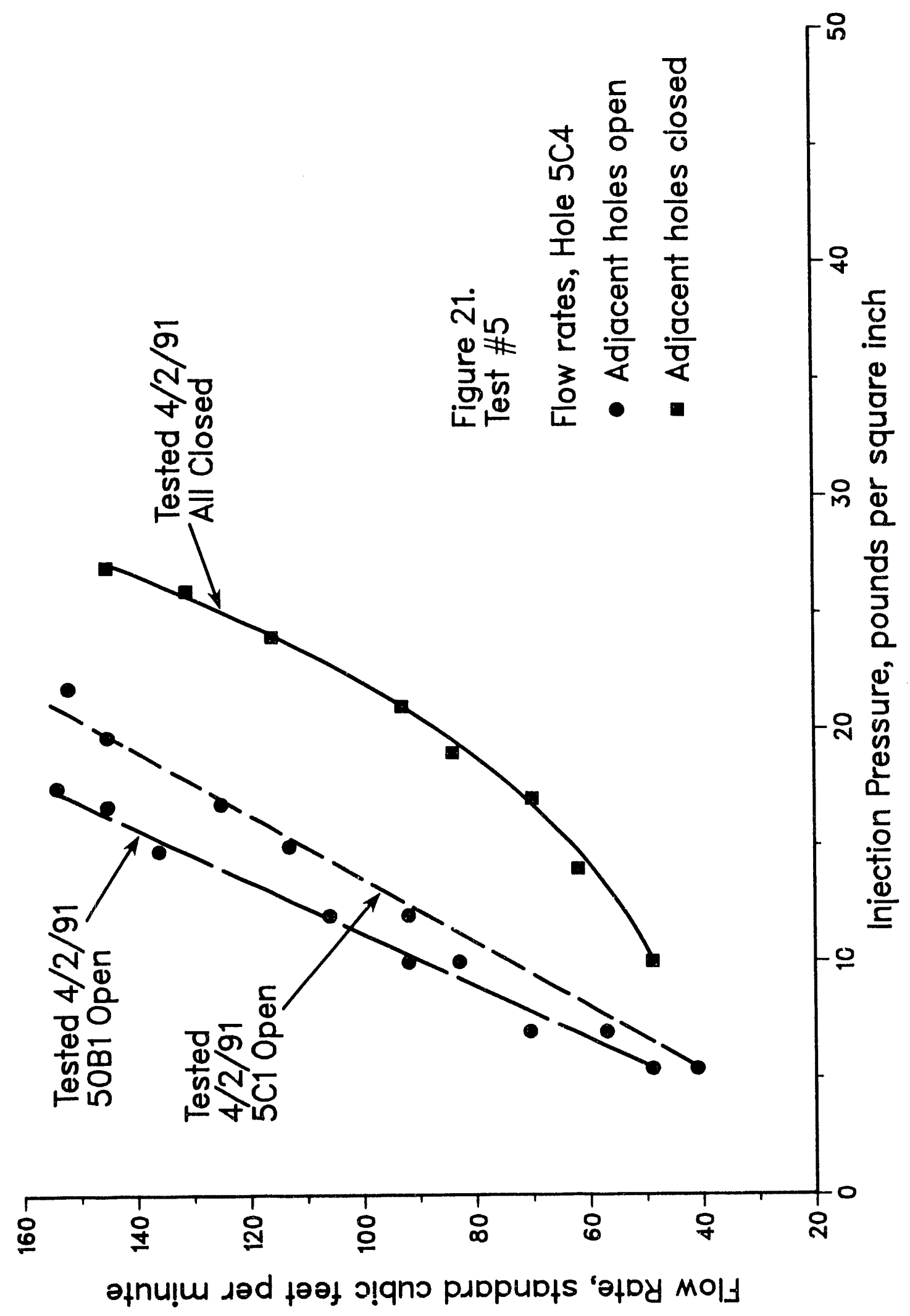




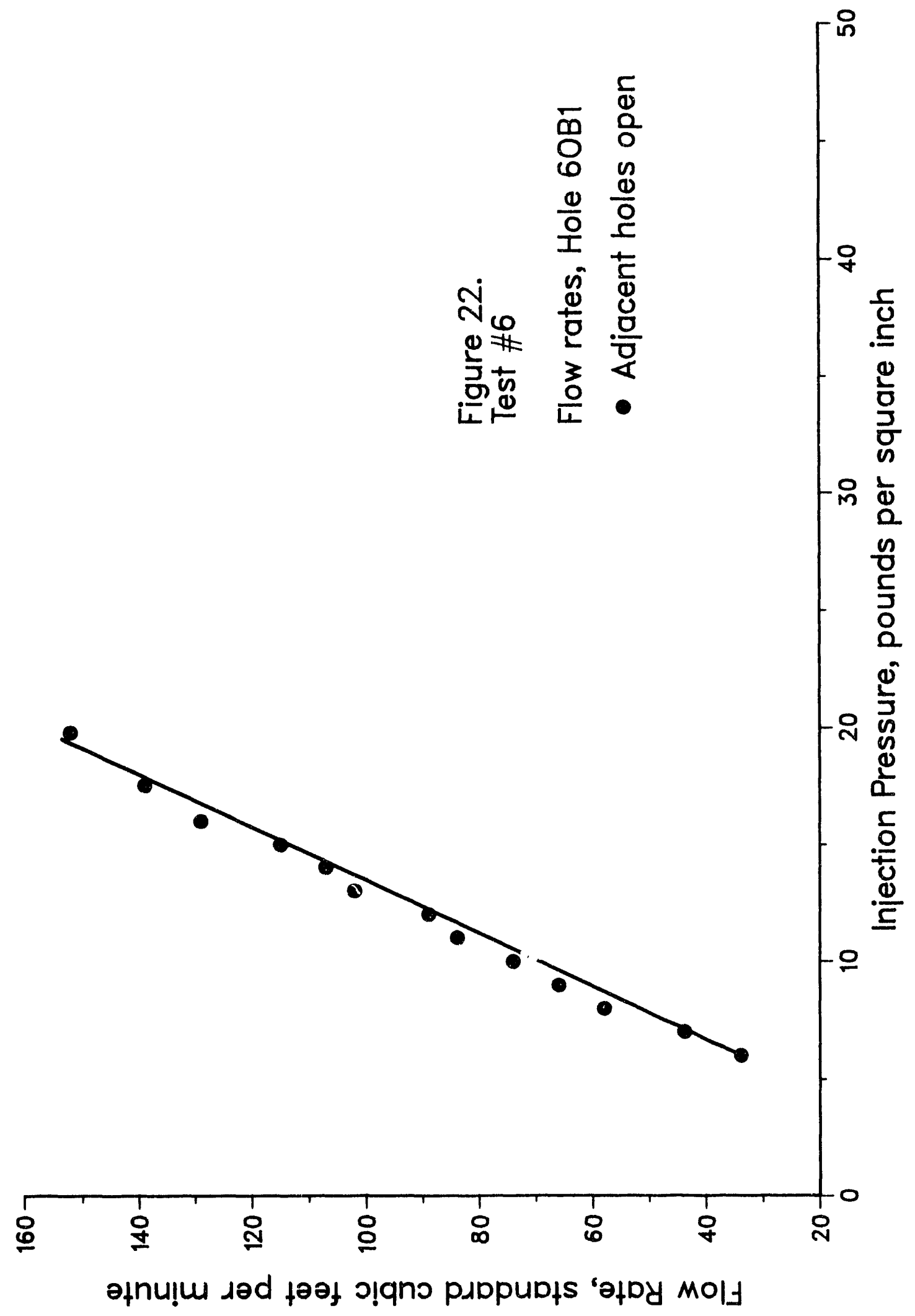


COREHOLE NO. GEOKINETICS COREHOLE EXP-10, 4128.4 FT N. AND

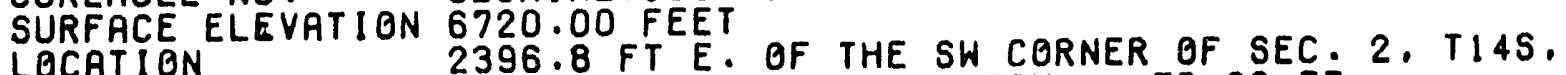
LOCATION R22E. UINTAH COUNTY, UTAH. TO $68 \mathrm{FT}$.

OIL YIELD--GALLONS PER TON (GPT)

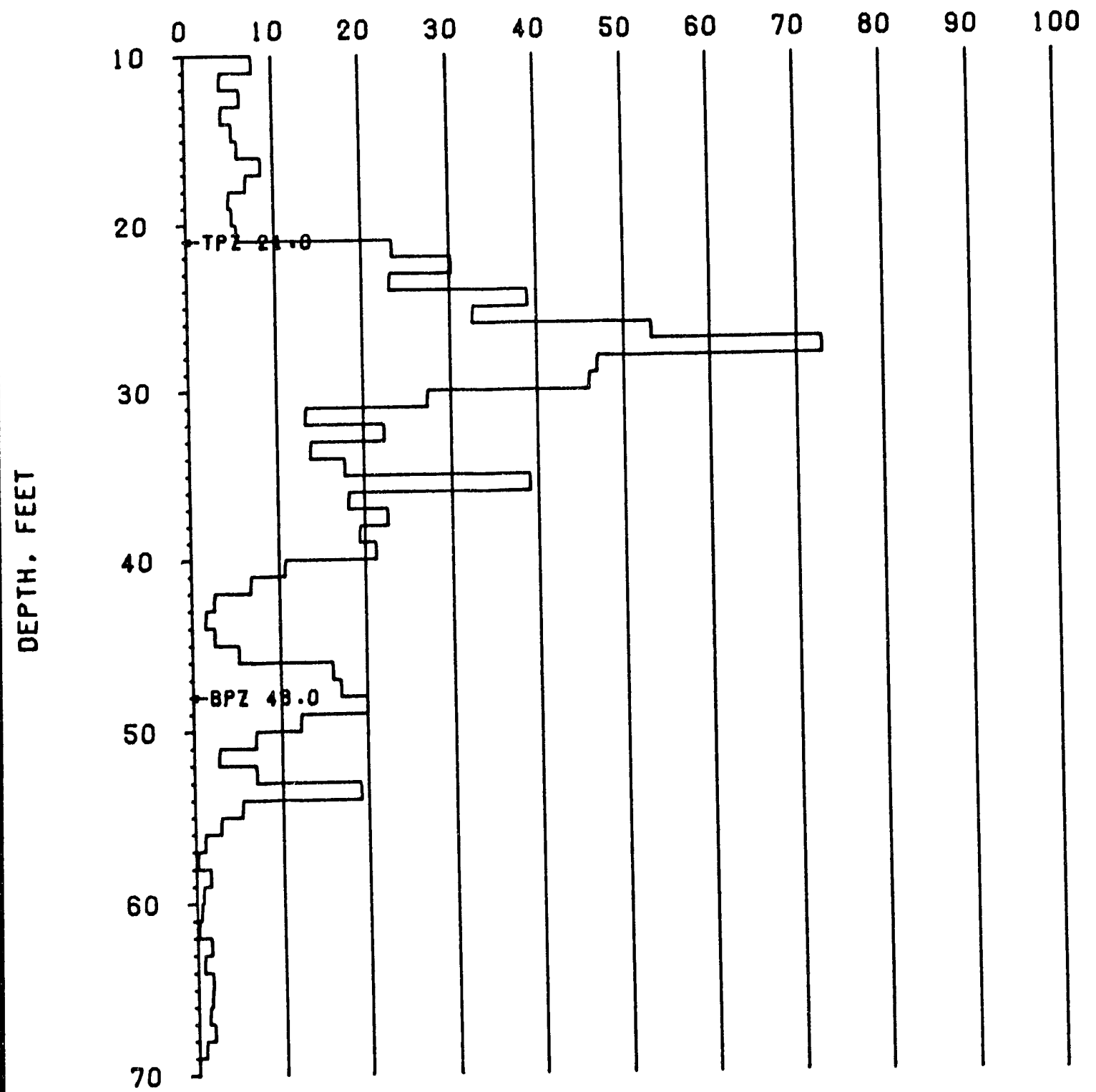

TOP OF PAY ZONE 21.0 FEET

BOTTOM OF PAY ZONE 48.0 FEET

PAY THICKNESS 27.0 FEET

AVERRGE GPT OF PAY ZONE 23.9

AVERAGE BARRELS PER ACRE FEET IN PLACE 1702.9

AVERAGE BARRELS PER ACRE IN PLACE 45978.5

Figure 23. Histogram of typical core hole in the test site area. 

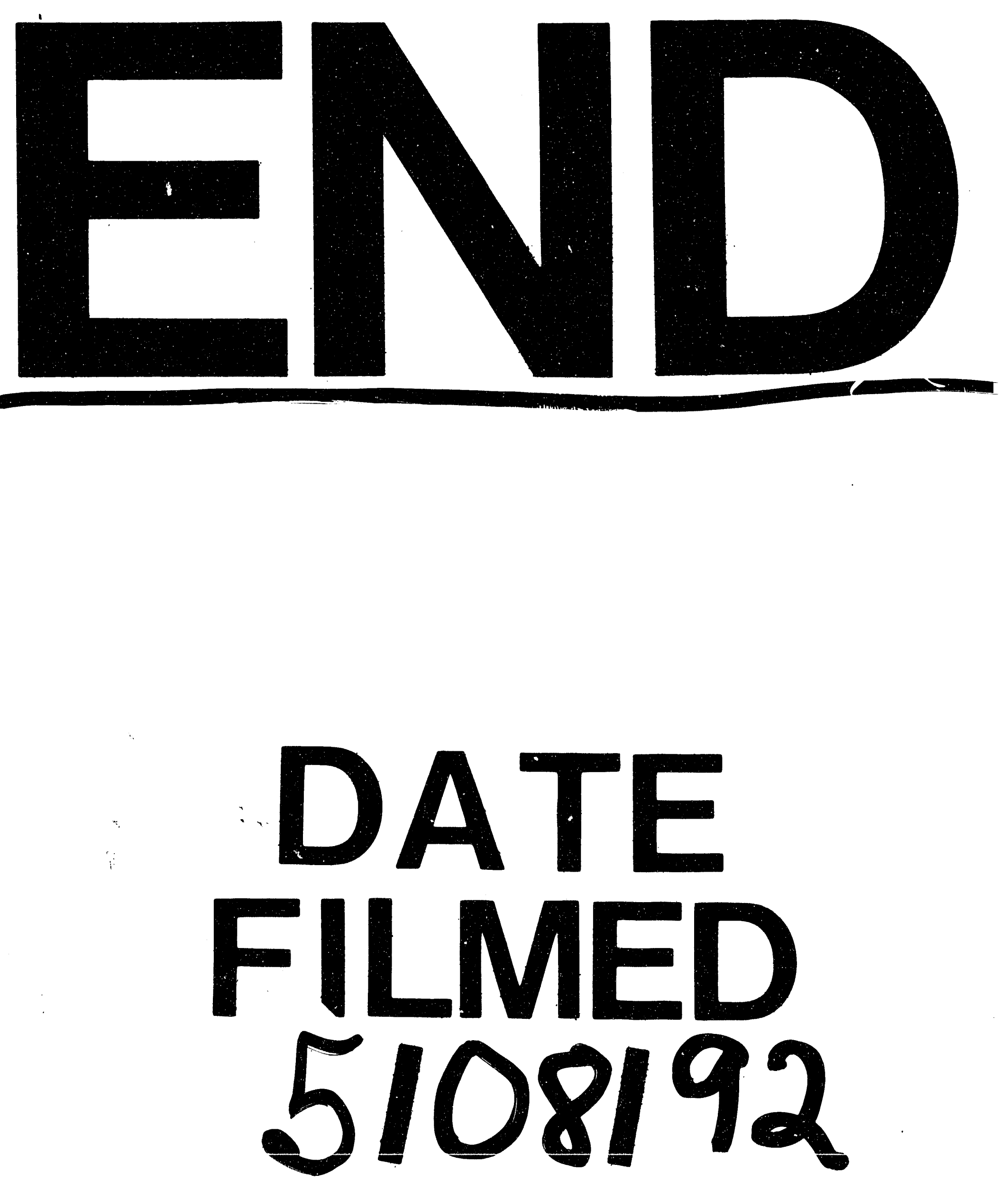
